
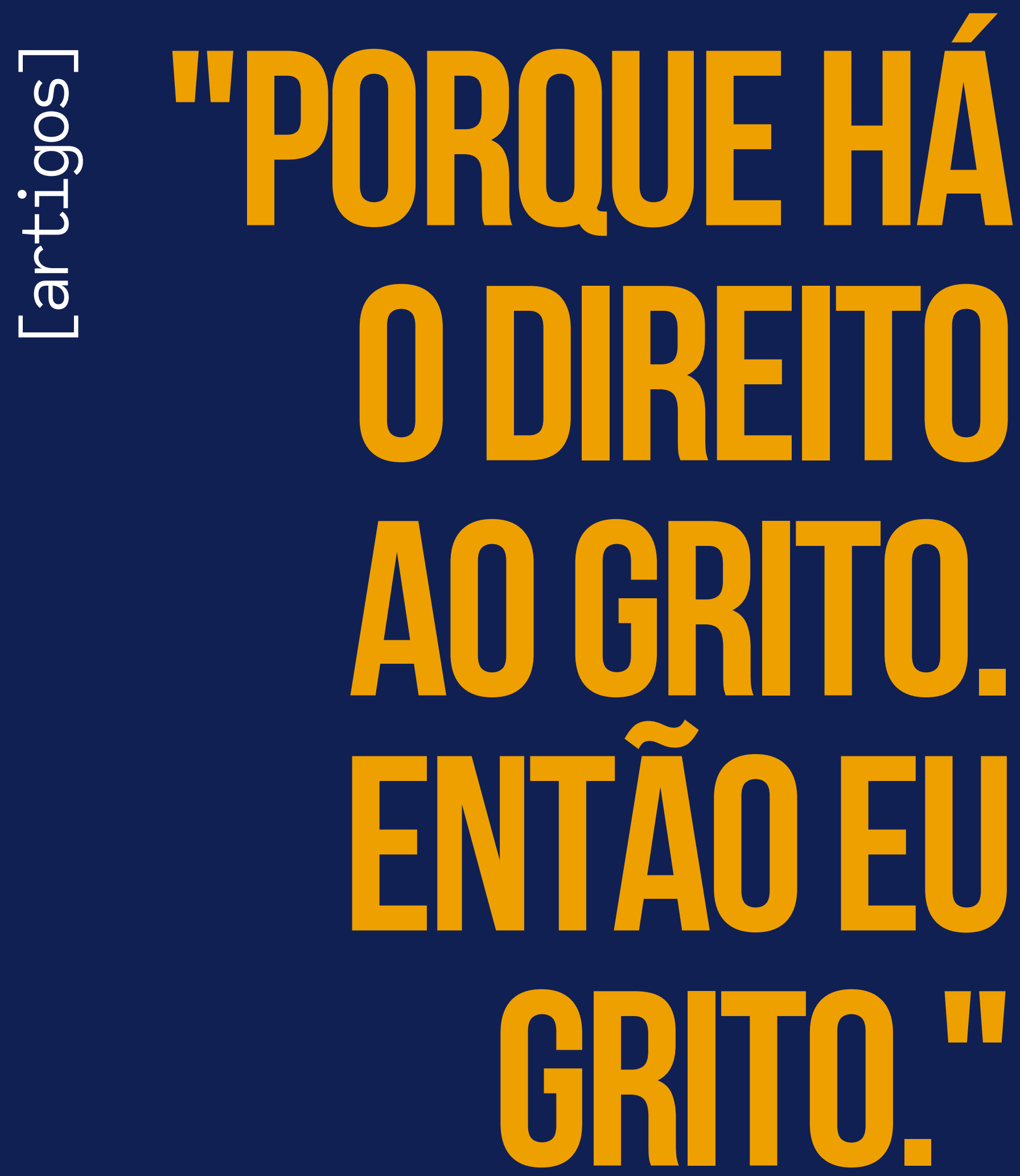

Carice Lispecto? 


\section{Consumo e liberdade: a anglomania nas vésperas da Revolução Francesa}

Consumption and freedom: Anglomania on the eve of French Revolution 


\section{Felipe Goebel ${ }^{1}$}

ORCID: https://orcid.org/0000-0002-0585-6890

[resumo 0 presente artigo analisa a formação de uma cultura de consumo na França das décadas de 1770 e 1780, enfatizando a contribuição da anglomania nesse processo. Nas décadas estudadas percebe-se uma busca por inspiração na Inglaterra, tanto no campo político como no cultural, por meio da emulação de costumes e trajes ingleses. Entendemos ainda que os trajes do período, de acordo com Roche (2007), criavam uma cultura das aparências que delimitavam as hierarquias, definindo o pertencimento e as demarcações dos grupos sociais. Nesse sentido, Ribeiro (2001) afirma que um novo entendimento cíclico sobre a moda permitiu que novas tendências de vestuário, cada vez mais popularizadas e de fácil acesso, fossem estabelecidas, o que alterou dramaticamente a base da cultura das aparências, necessária para a manutenção das práticas e representações do Ancien Régime. Defendemos que o entusiasmo da anglomania se fez presente não apenas nos trajes, como tendência a ser seguida, mas também influenciou o entendimento da sociedade e da política. Trajes esportivos, confortáveis e propícios para atividades ao ar livre aliaram-se a questionamentos sobre a sociedade de corte e a monarquia absolutista. Junto com as práticas indumentárias, veio a exaltação da naturalidade, da espontaneidade e da liberdade, em contrapartida ao controle do corpo e dos sentimentos. 0 modelo burguês trazido da Inglaterra, além disso, fortaleceu e ampliou uma cultura de consumo que já florescia em Paris. Dessa maneira, visamos demonstrar como a relação Inglaterra-França, nas décadas finais do Setecentos, no campo sociocultural, associou-se com os ideais revolucionários.

[palavras-chave] Anglomania. Consumo. Antigo Regime francês. Século XVIII.

\footnotetext{
${ }^{1}$ Mestre em História Social pela Universidade Federal do Rio de Janeiro - Programa de Pós-Graduação em História Social (PPGHIS-UFRJ). E-mail: goebel.felipeb@gmail.com. Lattes: http://lattes.cnpq.br/4374042309719542.
} 
[abstract] This paper analyzes the formation of a consumer culture in France, in the 1770s and 1780s, emphasizing the contribution of Anglomania to this process. In the studied decades, France found strong inspiration in England, both in the political and cultural fields, through the emulation of English habits and clothing. We also see that the costumes of the period, according to Daniel Roche, created a culture of appearances that delimited hierarchies, defining the belonging and demarcations of social groups. For that matter, Aileen Ribeiro argues that a new cyclical understanding of fashion allowed clothing trends, increasingly popular and easily accessible, to be established. This altered dramatically the basis of the culture of appearances, which was necessary for the maintenance of the practices and representations of the Ancien Régime. We argue that the enthusiasm of Anglomania was present not only in dressing as a tendency to be followed, but also influenced the understanding of society and politics. Comfortable sportswear, suitable for outdoor activities, was combined with questions about court society and the absolutist monarchy. Along with dressing practices came the exaltation of naturalness, spontaneity, and freedom, in contrast to with the control of body and feelings. The bourgeois model brought from England, furthermore, strengthened and expanded a consumer culture that was already flourishing in Paris. In this way, we aim to demonstrate how the relationship England-France, in the final decades of the $18^{\text {th }}$ century in the socio-cultural field, was connected to revolutionary ideals.

[keywords] Anglomania. Consumer. French old regime. $18^{\text {th }}$ century.

Recebido em: 23-10-2019

Aprovado em: 01-12-2019 


\section{A praticidade e o conforto dos trajes ingleses dominam Paris}

Roupas práticas e confortáveis, notáveis por uma alfaiataria altamente especializada, mas simples na sua confecção, feitas de lã e algodão de alta qualidade, eram apenas um dos muitos costumes que passaram a ser exportados da Inglaterra para a França a partir de meados da década de 1770. Com elas vieram também chás da tarde, partidas de whist, cricket e polo, corridas de cavalos e jardins pouco planejados. Apesar de a nação inglesa estar isolada geograficamente do resto da Europa, seus habitantes eram viajantes intrépidos. Eles levavam estilos únicos e inovadores para o continente por meio da chamada Grand Tour, as extensas viagens tradicionalmente feitas por ingleses e inglesas das classes média e alta quando completavam 20 anos. A contida e sóbria elegância das roupas masculinas inglesas - tão diferentes dos trajes rígidos, coloridos e pesadamente bordados usados pelos franceses - inspirou estilos variados que começaram a ser divulgados, emulados, adaptados e consumidos no continente europeu.

Desde a década de 1750, as inglesas passaram a viajar em um número sem precedentes, seguindo o já bem conhecido caminho da Grand Tour (NOLAN, 2001). Muitas dessas jovens viajavam para melhorar a saúde: Spa, Montpellier e Aix-la-Chapelle eram refúgios populares do clima chuvoso e frio da Inglaterra. Outras buscavam receber uma educação em cultura clássica em Roma, Nápoles e Florença. Compras, além disso, eram uma grande prioridade para as turistas inglesas: Paris, para roupas e adornos; Bruxelas, para rendas; e cidades italianas, para objetos de arte e antiguidades. Damas, com bons contatos sociais, eram apresentadas às cortes de Versalhes, Viena, Nápoles, Parma e Turim. Apesar de as viajantes inglesas desejarem comprar modas estrangeiras, e muitas vezes adotarem esses estilos em deferência ao gosto, aos hábitos e ao clima locais, sua visibilidade e seu prestígio social durante o reinado de Luís XVI e Maria Antonieta ajudaram a divulgar e a popularizar o denominado "estilo inglês" (goût anglais) na França e, por consequência, por toda a Europa. A ascensão do gosto inglês iniciou uma significante inversão na direção em que as modas eram lançadas e seguidas, as quais tradicionalmente haviam cruzado o Canal da Mancha da França para a Inglaterra, mas raramente ao contrário. Em 1786, a revista londrina Fashionable Magazine gabou-se: "Londres agora, falando genericamente, oferece as modas a Paris e, claro, para toda a Europa. Não Paris para Londres, mas Londres para Paris" (citado por GHERING VAN IERLANT, 1983, p. 64).

Porém, desde pelo menos o fim do século XVII, escritores, políticos, moralistas e caricaturistas ingleses haviam denunciado os efeitos corruptores das modas estrangeiras. As tendências francesas, sobretudo, eram consideradas particularmente perigosas. Os viajantes voltavam da França praticamente irreconhecíveis, tão forte era a pressão, ou o desejo, para adotar modos e maneiras afrancesadas. Além disso, esses modos e maneiras eram instantânea e servilmente copiados e adaptados nos centros urbanos da Inglaterra. Walpole

\footnotetext{
2 Tradução nossa para: "[...] London now, generally speaking, offers the fashions to Paris and, course, to all of Europe. Not Paris to London, but London to Paris".
} 
observou: "Todo mundo que vem de fora parece ter vindo da França, e seja o que for que use na sua primeira aparição pública imediatamente aumenta essa moda3" (WALPOLE, 1915, v. 4, p. 230). A supremacia da França em matéria de tendências a serem seguidas nas modas e na apresentação pessoal impunha ainda uma ameaça constante à economia inglesa, que se tornava cada vez mais dependente das manufaturas têxteis, e às fortunas de muitas famílias. Afirmava-se até que as modestas modas inglesas eram moralmente superiores às de seus espalhafatosos vizinhos católicos. Nesse sentido, nos seus Sermões para jovens mulheres, de 1766, o ministro presbiteriano James Fordyce perguntou:

Por que, filhas da Inglaterra, muitas de vocês são insensíveis às mais brilhantes glórias do seu sexo? Por quanto tempo vocês manifestarão a ambição de ostentar o traje francês, de se agitar com a leviandade desse povo fantástico? Quando vocês ficarão satisfeitas com a simplicidade da elegância e a graciosidade da modéstia, tornando, assim, em uma nação como esta, apoiada pelo comércio, polida pelo bom gosto e iluminada pela verdadeira religião? ${ }^{4}$ (FORDYCE, 1766, p. 46)

Porém, enquanto os moralistas ingleses esbravejavam contra as perniciosas influências francesas, os franceses passaram a apreciar os discretos encantos dos trajes ingleses. Ao passo que a França estabelecia os padrões de elegância para toda a Europa, os ingleses passaram a aperfeiçoar o que hoje é conhecido atualmente como sportswear. 0 gosto tipicamente inglês por atividades ao ar livre produziu um guarda-roupa específico, composto por peças que se destacavam pela funcionalidade sobre os embelezamentos, em que a função dominava a forma e a estrutura dos trajes. Muitas delas tinham origens rurais, incluindo botas de cano alto, perneiras, casacos e sobretudos. Esse estilo casual, usado tanto pela gentry proprietária das terras quanto pelos plebeus que trabalhavam nessas terras, desafiavam a formalidade, o luxo e a ostentação que distinguiam toda a estética aristocrática francesa. Rapidamente, os trajes ingleses tornaram-se sinônimos de roupas informais na França.

Enquanto o estilo francês distorcia e regulava o corpo, o estilo inglês acentuava-o e se adaptava a ele. Na França, camadas e mais camadas fortemente embelezadas e adornadas mascaravam formas e construções relativamente pobres. Ao contrário, os trajes ingleses eram caracterizados por cortes e construções meticulosas, sem distrações e excesso de camadas e embelezamentos. Mangas longas e justas, vestidos e casacos bem ajustados criavam uma silhueta que facilitava os movimentos. A diferença entre os estilos francês e inglês pode ser ilustrada ao contrastarmos o grand habit ou robe à la française (figura 1), com suas pregas

\footnotetext{
Tradução nossa para: "Everybody that comes from abroad is sensed to come from France, and whatever they wear at their first appearance immediately grown this fashion".

${ }^{4}$ Tradução nossa para: "Why, ye daughters of Britain, are so many of you insensible to those brightest glories of your sex? How long will you be ambitious of flaunting French attire, of fluttering about with the levity of that fantastic people? When will you be satisfied with the simplicity of elegance, and the gracefulness of modesty so becoming in a nation like this, supported by trade, polished by taste and enlightened by true religion?".
} 
pesadas e seus pitorescos embelezamentos sobrepostos, com o robe à l'anglaise (figura 2), com sua silhueta mais ajustada ao corpo e menos decorações sobrepostas. Ainda que similares e formais, o chamado à inglesa era bem menos decorado, feito de tecidos mais leves, marcado por um corpete menos apertado, com poucas sobreposições, sem cauda e sem a prega traseira. Os dois tipos de vestido eram usados ao mesmo tempo por toda a Europa, inclusive na França, ao longo da metade final do Setecentos.

FIGURA 1 - JEUNE DAME DE QUALITÉ EN GRANDE ROBE. 1778. CLAUDE LOUIS DESARIS. GRAVURISTA: ETIENNE VOYSARD (GRAVURA COLORIDA À MÃO SOBRE PERGAMINHO, 38 X 24 CM)

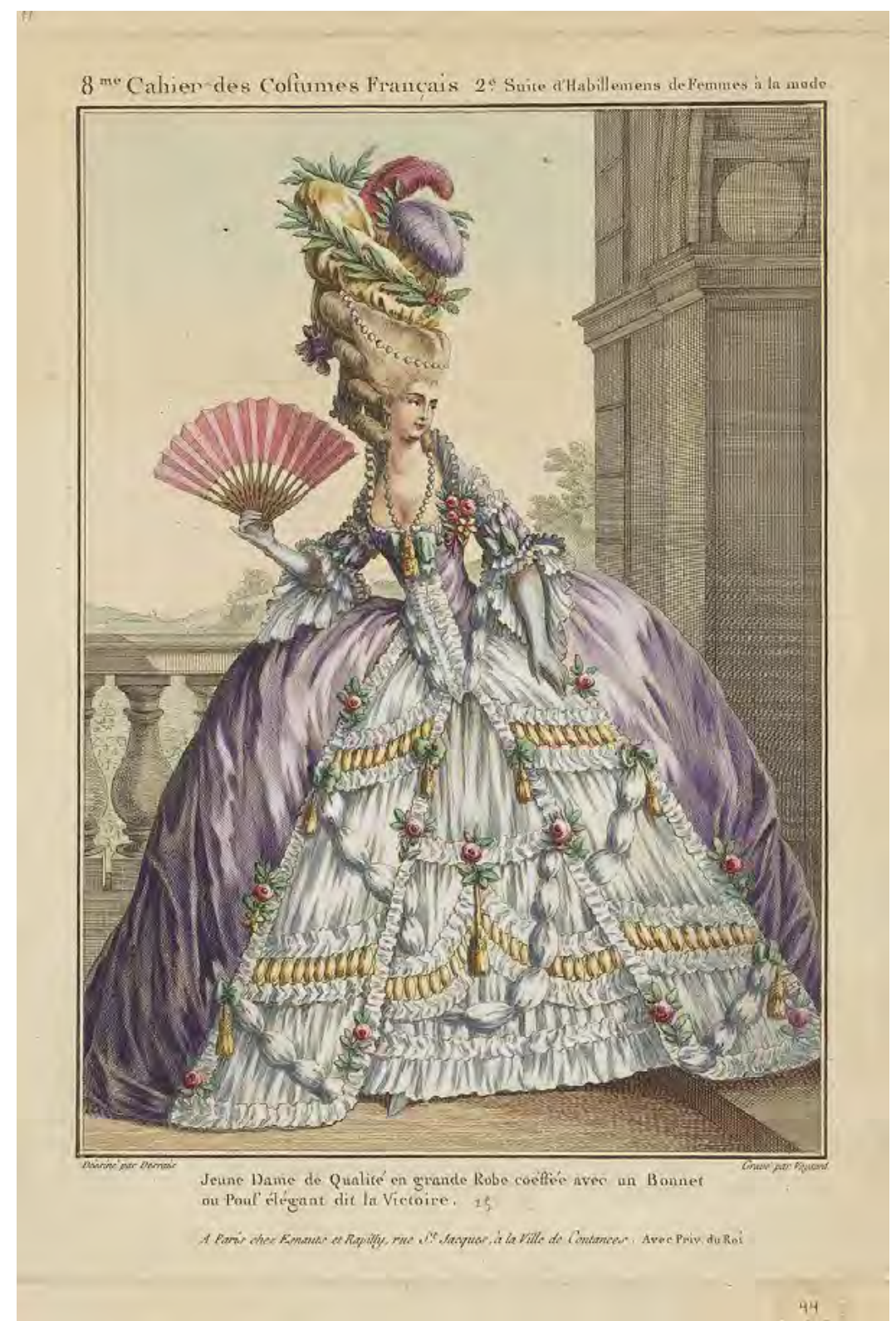

FONTE: Gallerie des Modes. $8^{\circ}$ caderno de trajes franceses. $2^{\mathrm{a}}$ suíte de roupas de mulheres na moda. Disponível em: https://collections.mfa.org/objects/312580/. Acesso em: 22 out. 2019. 
FIGURA 2 - ROBE À L'ANGLAISE GARNIE À PLIS PLATS BORDÉ D'UN FRISÉ DE MOUSSELINE. 1784. CLAUDE LOUIS DESARIS. GRAVURISTA: ETIENNE VOYSARD

(GRAVURA COLORIDA À MÃO SOBRE PERGAMINHO, 38 X 24 CM)

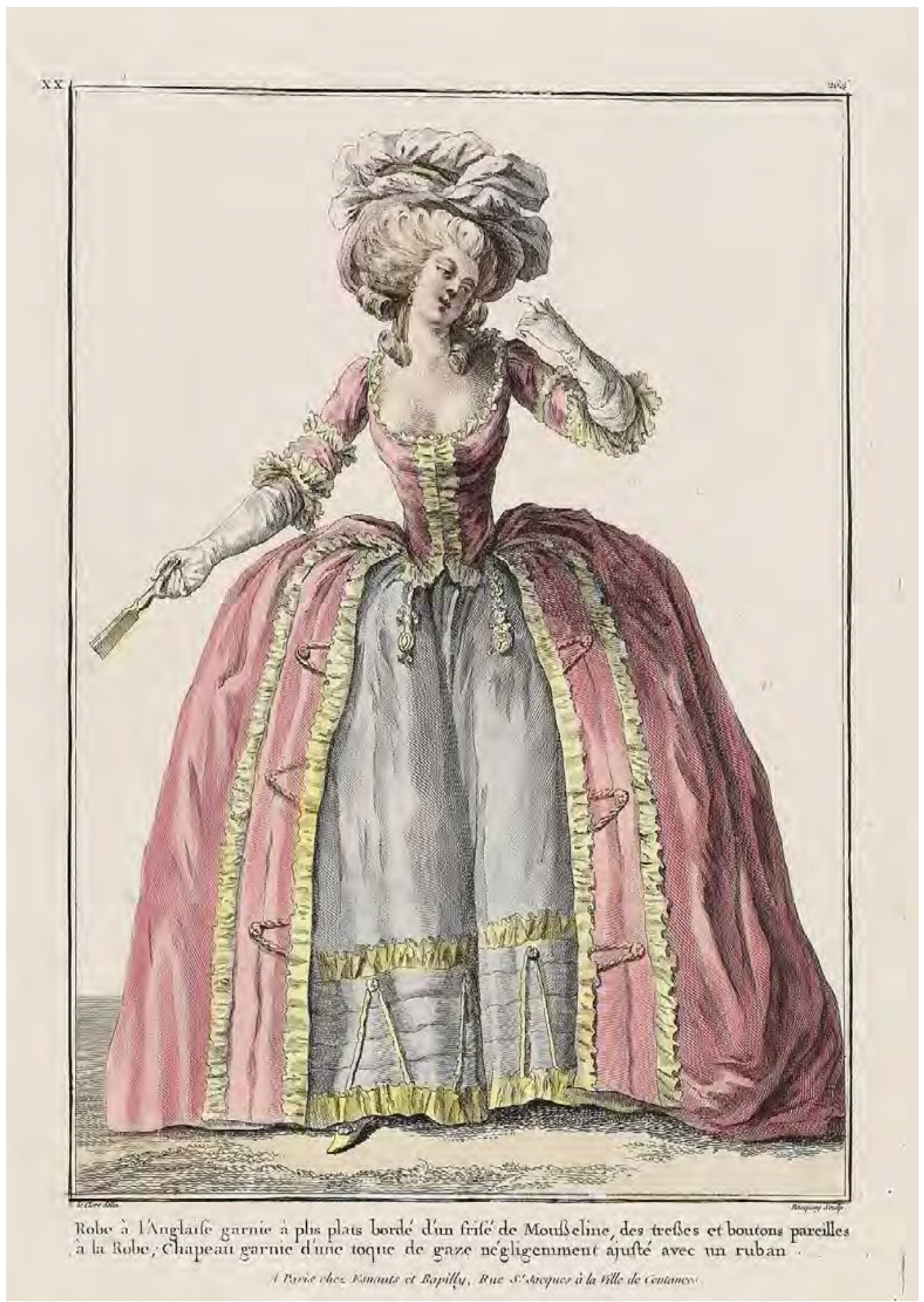

FONTE: Gallerie des Modes. $41^{\circ}$ caderno de trajes franceses. $36^{a}$ suíte de roupas de mulheres na moda. Disponível em: https://collections.mfa.org/objects/352866/. Acesso em: 22 out. 2019. 
Na maior parte das cortes europeias, o robe à la française era o traje oficial esperado de uma dama. Eventualmente, porém, o robe à l'anglaise triunfou e passou a ser aceito nas cortes. A partir de 1785, o robe à la française passou a ser usado apenas em ocasiões muito formais, quando a liberdade de movimento não era necessária e a exibição e a distinção constituíam o mais importante. Ele era denominado de vestido saco atrás (sack-back dress) na Inglaterra, por causa da prega característica ${ }^{5}$, para distingui-lo de sua variedade nacional (figura 3). De maneira reveladora da forte influência francesa, os trajes de inspiração inglesa foram chamados de robe à l'anglaise, em francês, para os vestidos ajustados e simples que refletiam o novo bom gosto. 0 gosto por trajes e passatempos oriundos da Inglaterra intensificou-se a partir de 1770; as tendências culturais e políticas advindas daí convergiram para produzir um animado clima de anglomania (anglomanie) nas principais cidades francesas, sobretudo Paris e Lyon. Em 1788, o jornal Tableau de Paris lamentava-se que Paris havia sido dominada por "roupas, carruagens, cavalos, jóias, bebidas, peças, jardins e morais inglesas... Pegamos o Vauxhall, os clubes, as corridas de cavalo, fraques, whist e boxe dessa triste Nação" (MERCIER, 1800, v. 2, p. 165). A anglomania tinha um apelo especial tanto para os philosophes, inspirados sobretudo por Rousseau, como para as petites-maîtresses e os petit-maîtres - o grupo de seguidores ávidos das novas tendências de moda, advindos dos mais diversos setores sociais. Proeminentes anglófilos como Maria Antonieta, que reformou inteiramente seu retiro pessoal, o Petit Trianon, no estilo rural inglês, incluindo uma fazenda modelo seguindo os princípios de produção e de gerenciamento ingleses, o Conde d'Artois (irmão mais novo de Luís XVI) e o Duque d'Orleans (proprietário do Palais Royal) cercavam-se de ingleses tanto nobres como plebeus. A meio inglesa Marquesa de La Tour du Pin comentou, em 1787: "Era necessário que tudo fosse inglês - da nossa inexistente Constituição aos nossos cavalos e carruagens. Eu era frequentemente invejada em locais públicos por ter a boa sorte de evocar a exclamação "Voilà une Anglaise!?" (LA TOUR DU PIN, 1820, p. 68)

\footnotetext{
A cauda le sac é um componente importante no traje feminino formal francês (grand habit e robe à la française) dos séculos XVII e XVIII. Basicamente, a cauda era uma prega dupla, ou simples, feita na parte de trás do vestido de cima, na altura dos ombros. A prega formava, dessa maneira, uma espécie de capa em formato de saco (daí o nome) que se estendia das omoplatas até o chão. Ela é chamada, na maioria dos manuais de História da Moda, de prega Watteau ou prega à la Watteau, em referência ao pintor que tão frequentemente as retratou em seus quadros e gravuras. Porém o termo prega Watteau não era utilizado no século XVIII, conforme aponta Laura Ferrazza de Lima (2018), em estudo inédito sobre as gravuras de trajes realizadas pelo artista. 0 termo surge somente no Segundo Império (1852-1870); trata-se, portanto, de uma invenção dos costureiros e estilistas de alta-costura do século XIX como forma de denominar uma peça típica do Setecentos e do Ancien Régime, na esteira da reconstituição de uma tradição monárquica e aristocrática fortemente idealizada, uma das características do reinado de Napoleão III e Eugênia. Nas duas revistas analisadas aqui (Cabinet des Modes e Magasin de Modes Nouvelles), o termo prega Watteau não aparece sequer uma única vez; le sac, porém, designa a cauda que ia das omoplatas ao chão no traje formal de corte chamado robe à la française. Os ingleses chamavam o traje francês, com sua pesada prega e cauda traseira, de sack-back dress (vestido saco atrás, literalmente), opondo-o de maneira irônica ao traje feminino tipicamente inglês, que não adotava a prega, a cauda e o espartilho grand corps.

6 Tradução nossa para: "clothes, carriages, horses, jewelry, drinks, parts, gardens and English morals... We took the vauxhall, clubs, horse races, whist and boxing of this sad Nation".

Tradução nossa para: "it was necessary that everything should be English - from our non-existente Constitution to our horses and carriages. I was often envied because in public places I had the good fortune to evoke the exclamation, 'Voilà une Anglaise!'”.
} 
FIGURA 3 - JEUNE DAME EN ROBE DE TAFFETAS DE COULEUR À VOLONTÉ. 1778. CLAUDE LOUIS DESARIS. GRAVURISTA: ETIENNE VOYSARD (GRAVURA COLORIDA À MÃO SOBRE PERGAMINHO, 38 X 24 CM)

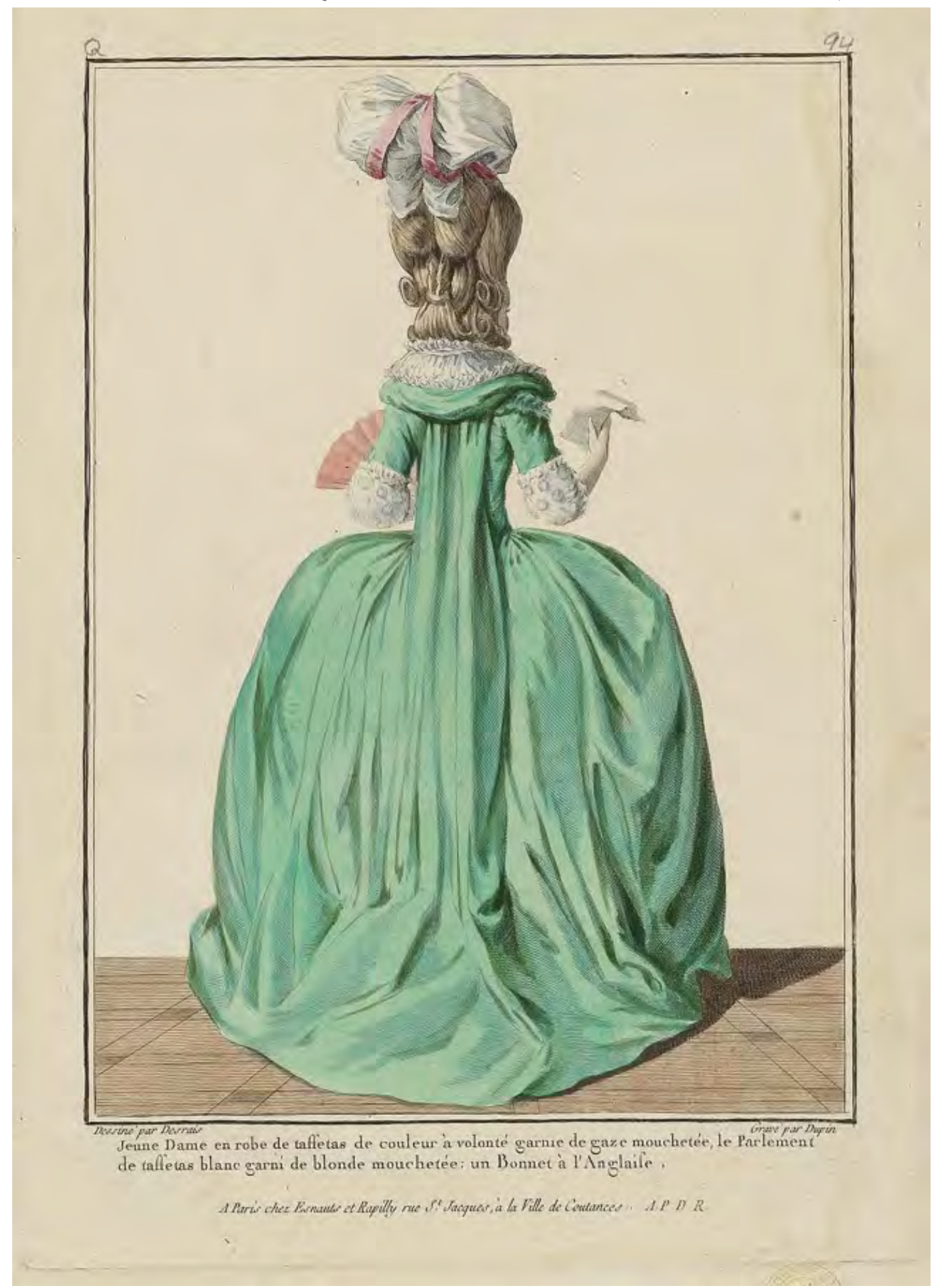

FONTE: Gallerie des Modes. $16^{\circ}$ caderno de trajes franceses. $10^{a}$ suíte de roupas de mulheres na moda. Disponível em: https://collections.mfa.org/objects/312645/. Acesso em: 22 out. 2019. 


\section{Le frac, chapéus e redingotes}

A sobrecasaca masculina usada na Inglaterra, le frac como foi divulgado pela Europa, era identificada pelo seu corte econômico que empregava pouco tecido, com o colarinho característico, dobrado ou virado para baixo. Era usada normalmente com um colete simples, culotes de lã ou algodão grosso em cores escuras e botas de couro, um pouco abaixo dos joelhos. Já em 1768, Caraccioli observou que jovens franceses "acham o frac o mais elegante e conveniente dos casacos", assinalando que "às vezes há mais arte nos trajes deshabillés [trajes informais] do que nos trajes formais" (CARACCIOLI, 1772, p. 76). Assim como o robe à l'anglaise, o fraque ganhou o estatuto imprevisto de sofisticação e elegância conforme conquistava admiradores por toda a Europa.

No retrato pintado em 1781, por Wright de Derby, Sir Brooke Boothby aparece usando o fraque com coletes e calções com perneiras (figura 4). Wright transmite no retrato a crença de Rousseau na importância do homem em viver em harmonia com a natureza, da maneira mais natural e espontânea possível. Ele escolheu deliberadamente o formato paisagem, representando o poeta deitado ao lado de um riacho em um cenário de bosque. Importante na composição é o livro que Boothby está segurando, como se estivesse lendo e meditando sobre o que leu. 0 poeta aponta, com o dedo indicador esquerdo, o nome Rousseau, inscrito na lombada do livro. Cerca de dez anos antes, Boothby entrou em contato com Rousseau, em Paris, e o filósofo confiou-lhe o manuscrito para o primeiro volume de seus diálogos autobiográficos, que ele desejava publicar preferencialmente na Inglaterra. Como resultado, Juge de Jean Jacques foi publicado em 1780, dois anos após a morte de Rousseau, com edição e comentários de Boothby. A fama de homem de letras influente na Europa é um dos dados que torna possível entendermos o porquê de o retrato ter se tornado um dos modelos pictóricos para representar os novos pensadores do período - os denominados philosophes. Por sua proximidade com as ideias rousseaunianas de naturalidade e conforto, o tradicional uniforme usado pelos senhores rurais ingleses foi adaptado e transformado no distintivo visível dos racionalistas franceses.

Agrande musa inglesa que até mesmo reivindicou o título de petite-maîtresse (ou fashionable lady, em inglês) foi a polêmica Georgiana Cavendish, Duquesa de Devonshire, amiga de Maria Antonieta e frequente visitante de Paris. A fama de Georgiana na França não era apenas fruto da anglomania. Pelo contrário, ela pode ser considerada um dos muitos fatores que contribuíram para a loucura por modas e maneiras inglesas no fim da década de 1770 e no início da de 1780 em Paris e Versalhes. No verão de 1779, Georgiana fez uma de suas visitas periódicas ao balneário de Spa, quando voltava para a Inglaterra depois de passar alguns dias na corte francesa, onde ficou hospedada no Petit Trianon de Maria Antonieta. Essa visita inspirou a criação do chapeau à la Devonshire, também conhecido como chapeau à la Spa, e outros similares que foram divulgados pelas publicações de moda de Paris, sobretudo a Gallerie des Modes. Esses

\footnotetext{
8 Tradução nossa para: "trouver le frac le plus élégants et plus pratiques des manteaux. Parfois, il y a plus d'art dans les deshabillés que dans les costumes formels".
} 
chapéus de abas largas eram feitos de feltro ou palha inglesa e arrematados com uma fita larga de seda, plumas brancas ou coloridas e algumas flores naturais. Chapéus decorados com plumas e flores combinavam a exuberância do pouf, penteado obrigatório na década de 1770, com a novidade dos chapéus femininos, um artigo até então usado somente por homens na França.

FIGURA 4 - SIR BROOKE BOOTHBY. 1781. JOSEPH WRIGHT DE DERBY (ÓLEO SOBRE TELA, 14,9 X 20,8 CM)

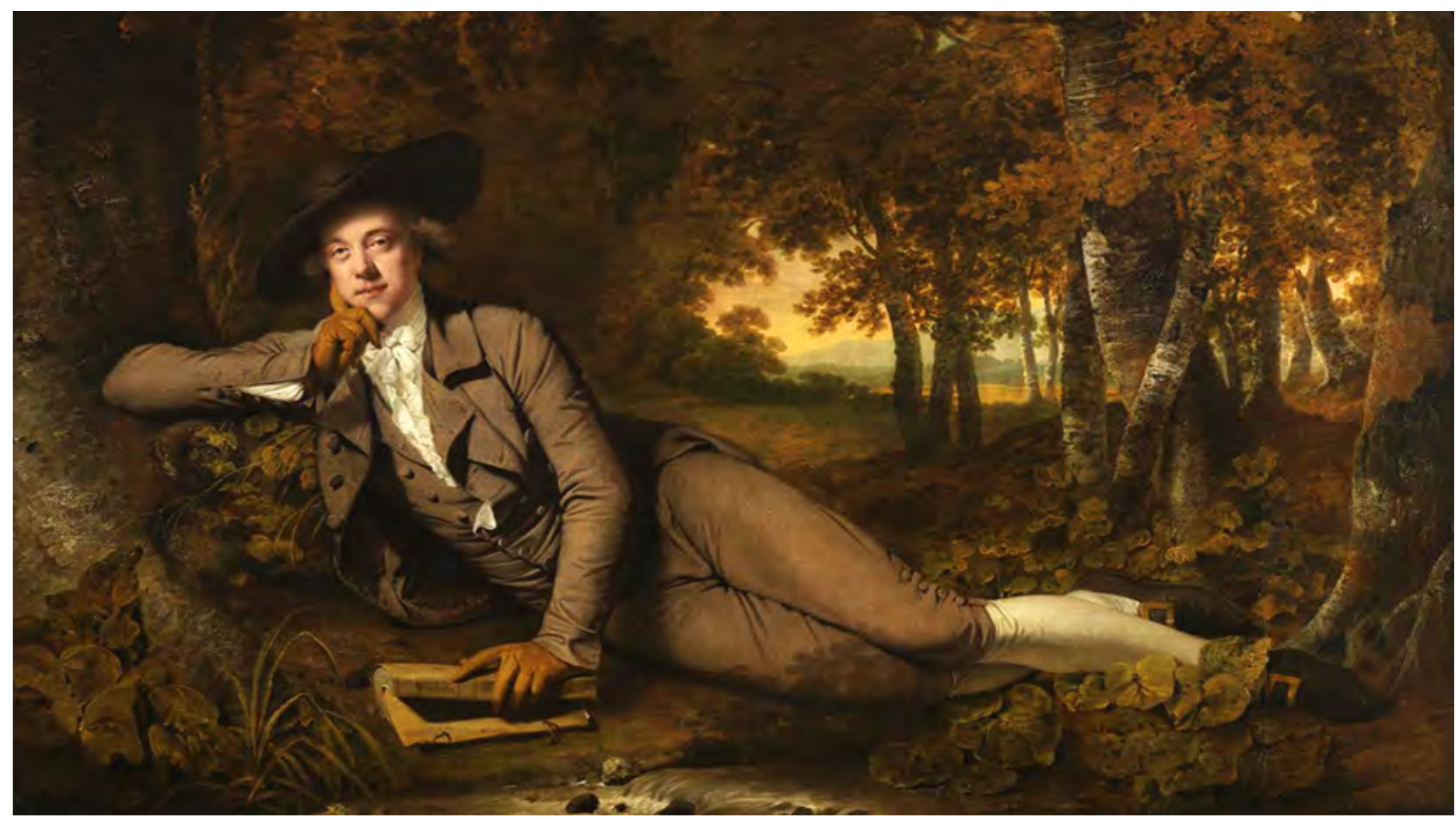

FONTE: Tate Gallery, Londres. Disponível em: https://www.tate.org.uk/art/artworks/wright-sir-brookeboothby-n04132. Acesso em: 22 out. 2019.

Rapidamente os chapéus viriam substituir o pouf em matéria de toucado na moda. Embora denominados de chapéus ingleses, chapeau à l'anglaise, eles tinham pouca semelhança com aqueles que as mulheres inglesas usavam. Tanto que Eliza de Feuillide, prima de Jane Austen, testemunhou, ao visitar Paris em 1779, que eles

[...] não mantêm a mínima semelhança com aqueles usados na nossa Nação. Os daqui são enormes, pesados e pouco práticos, decorados com todo tipo de flores e plumas. Não é raridade apanharmos com as abas enormes dos chapéus das mulheres da moda, e nos teatros e na Ópera às vezes fica difícil de assistir o palco, caso sente-se atrás de uma delas usando esses monumentos de palha, fitas, laçarotes, flores e plumas altíssimas. (LE FAYE, 2002, p. 46)

\footnotetext{
9 Tradução nossa para: "Do not bear the least ressemblance to those of our Nation. Those from here are huge, heavy and little practical, decorated with all kind of flowers and plumes. It is not rare that one was punched by the enormous flaps of the hats of fashionable women, and in the theaters and in the Opera sometimes is difficult to watch the stage, if one sits behind of one wearing these
} 
Além disso, eles eram usados sobre cabelos empoados, o que arruinava de certa maneira o efeito natural e rústico original, uma vez que as inglesas usavam cabelos com pouco ou nenhum pó.

Claramente, a Duquesa de Devonshire empolgava-se com toucados estilizados. Previamente, ela havia sido criticada na Inglaterra por adotar maneirismos franceses e usar os extravagantes poufs, marca registrada de Maria Antonieta e de seu círculo íntimo no período (FOREMAN, 2012, p. 53). Por volta de 1785, Thomas Gainsborough pintou-a usando um enorme chapéu - de fato maior do que seu rosto - similar aos em voga em Paris, bastante decorado com plumas bem altas e, alegadamente, uma de suas criações (figura 5). Georgiana usa um vestido chemise simples de algodão branco, amarrado na cintura por uma fita e um laço. Ela é retratada sobre um fundo escuro, possivelmente arborizado. 0 enorme chapéu estilizado, as luvas, os cabelos quase soltos e sem pó e a rosa que segura dão o tom despojado, de naturalidade e de atividade ao ar livre. Quando o retrato foi exibido na Royal Academy, as inglesas imediatamente começaram a exigir cópias do chapéu do quadro da Duquesa. Em poucas semanas, esse tipo de chapéu cruzou o Canal da Mancha: em 1786, a Cabinet des Modes estreou em suas páginas um novo tipo de chapeau à la Devonshire, similarmente emplumado e arrematado e combinado com um robe à l'anglaise completo. Nesse período, o termo à la Devonshire passou a ser sinônimo de à l'anglaise para as petites-maîtresses de Paris (figura 6).

Os estilos vinculados à anglomania são alguns dos poucos que se tornaram populares igualmente entre ambos os sexos. Enquanto as francesas adotavam o robe à l'anglaise e também os chapéus e importavam gazes de algodão e lãs inglesas, os franceses começavam a aparecer em sociedade usando o frac, perneiras de couro, botas e capas de jockey. Ambos os sexos passaram a usar casacos e jaquetas ajustadas (jacquets) e chapéus de abas largas, o que era considerado, na França, a quintessência do costume inglês. 0 rouge, os cabelos muito empoados e encaracolados, anteriormente considerados indispensáveis para a elite aristocrática, rapidamente caíram em desuso na busca por aparências mais naturais.

Em novembro de 1786, a revista Cabinet des Modes - principal publicação francesa em circulação dedicada exclusivamente à moda - mudou seu nome para Magasin des Modes Nouvelles Françaises et Anglaises, reconhecendo, assim, a crescente importância das tendências vindas da Inglaterra. 0 primeiro número sob esse título incluía duas gravuras das chamadas Modes Angloises: o homem usa um traje de lã da "cor da fuligem das chaminés de Londres" com culotes cor de creme e um grande chapéu com fivela, denominado chapeau de jockai, botas de couro, perneiras abotoadas e esporas, enquanto sua companheira usa um grande chapéu de feltro, uma sobrecasaca e um sobretudo de lã "verde-garrafa" com mangas em estilo náutico (à la marinière), uma camisa de estilo e colarinho masculino e "uma ampla gravata com babados, amarrada meio solta, de maneira parecida com a dos homens" (MAGASIN DES MODES NOUVELLES, Primeiro caderno, 20 de novembro de 1786). Ambos usam luvas de couro e carregam varas flexíveis, similares a chicotes, utilizadas para montar.

monuments of straw, ribbons, laces, flowers and high feathers". 
Os trajes são creditados a um alfaiate francês, Monsieur Jubin do Palais Royal (figura 7). Ainda que muitos dos chamados estilos ingleses fossem criados por profissionais franceses, tecidos e matérias-primas importados diretamente da Inglaterra eram preferíveis.

Uma das mais populares tendências femininas vindas da Inglaterra, e usadas ostensivamente nos bulevares e passeios de Paris pelas petites-maîtresses, foi o traje de montaria. Ele era formado por peças avulsas que podiam ser recombinadas, sobreposições de saias e anáguas de algodão, casaca e sobretudo de mangas compridas, abotoados elegantemente abaixo dos seios. Originalmente usado para caçadas e cavalgadas, já no final da década de 1750, esse traje passou a ser considerado uma roupa urbana informal e elegante, apropriada para uma grande variedade de passatempos ao ar livre, desde caminhadas, piqueniques e até mesmo concertos e leituras públicas. Era, além disso, uma escolha prática entre as damas que realizavam o Grand Tour.

FIGURA 5 - GEORGIANA, DUCHESS OF DEVONSHIRE. 1785. THOMAS GAINSBOROUGH

(ÓLEO SOBRE TELA,127 X 101,5 CM)

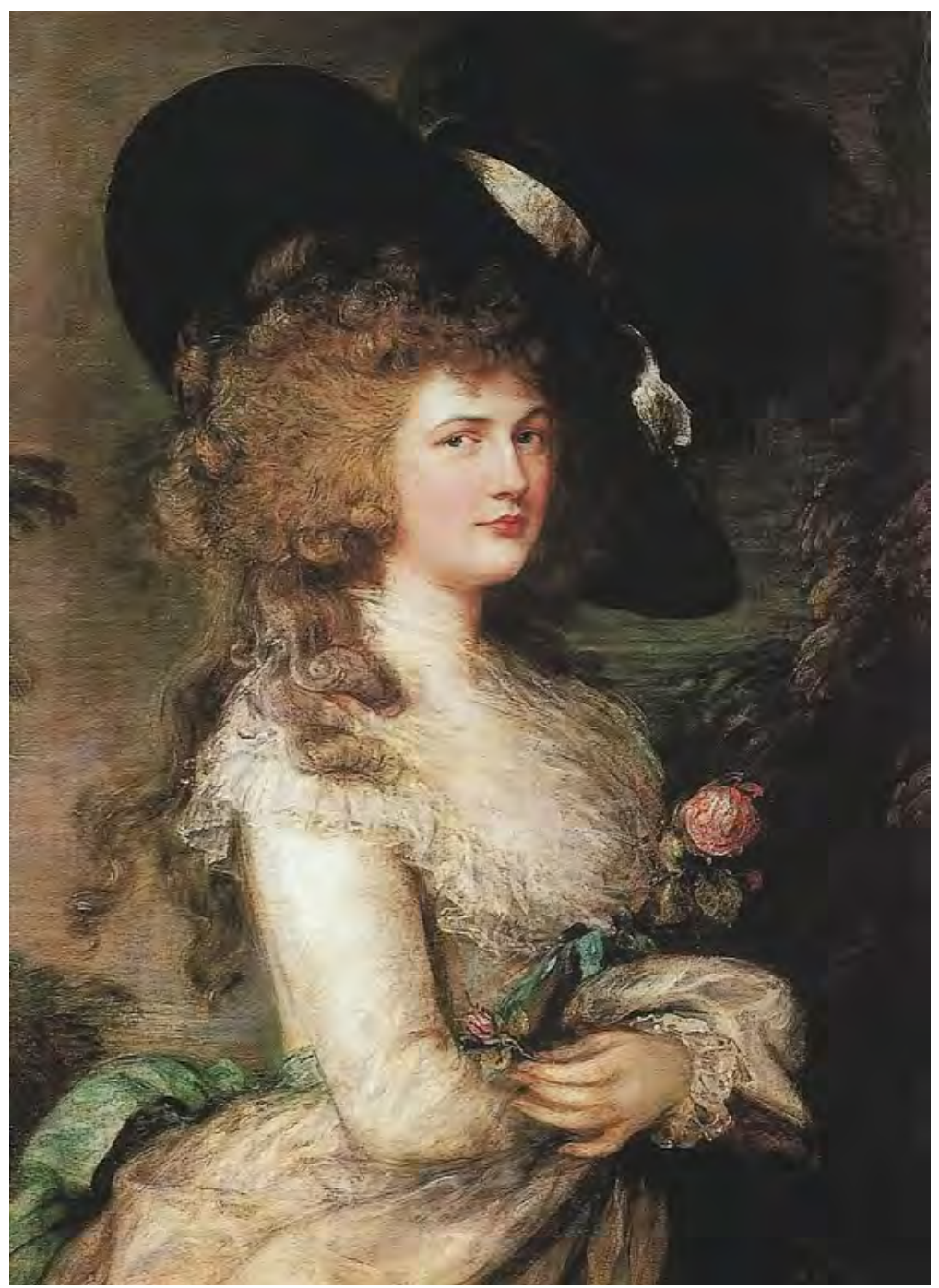

FONTE: Chatsworth House, Derbyshire. Disponível em: https://commons.wikimedia.org/wiki/ File:Thomas_Gainsborough_Lady_Georgiana_Cavendish.jpg. Acesso em: 22 out. 2019. 
FIGURA 6 - CHAPEAU À L'ANGLAISE, CHAPEAU À LA DEVONSHIRE. 1786. DUHAMEL (GRAVURA COLORIDA POR PRENSA, 34 X 26 CM)

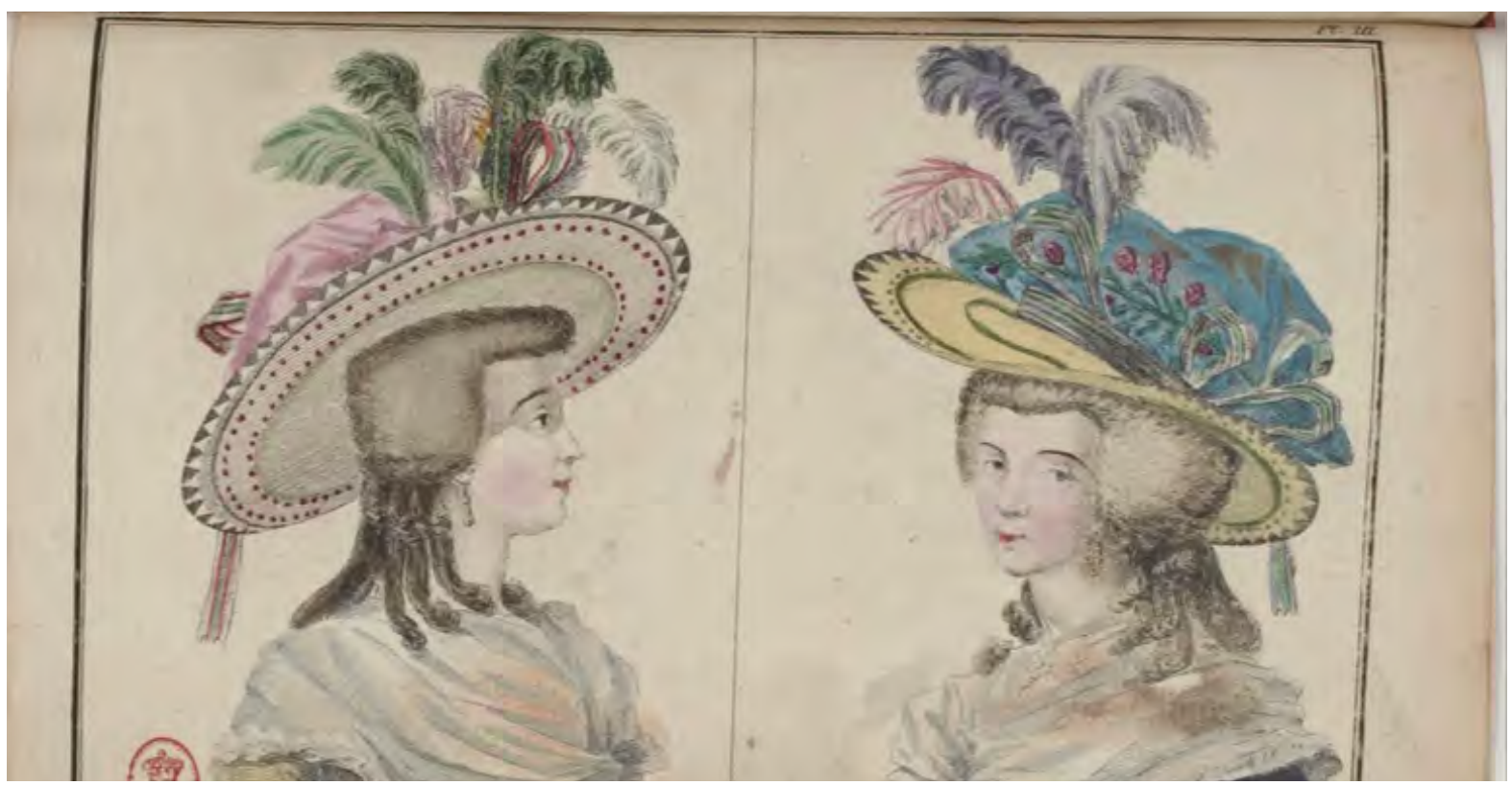

FONTE: Cabinet des Modes. $18^{\circ}$ caderno, $1^{\text {o }}$ de agosto de 1786. Disponível em: https://gallica.bnf.fr/ ark:/12148/bpt6k1040056n?rk=42918;4. Acesso em: 22 out. 2019.

FIGURA 7 - BEAU COUPLE EN MODES ANGLOISE..., 1786. DUHAMEL

(GRAVURA COLORIDA POR PRENSA, 34 X 26 CM)

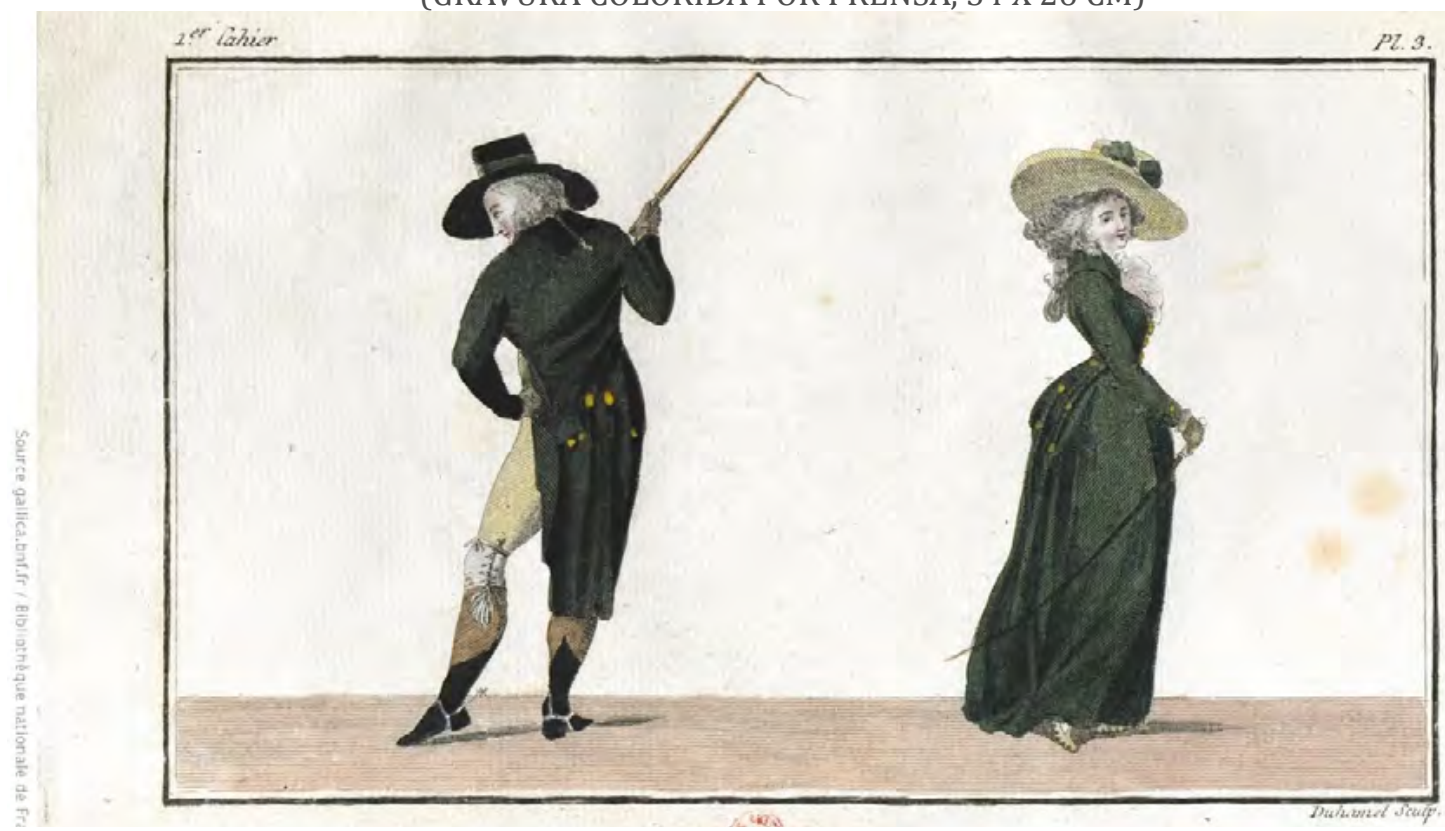

FONTE: Magasin des Modes Nouvelles Françaises et Angloises. $2^{\circ}$ Ano. $1^{\circ}$ caderno, 20 de novembro de 1786. Disponível em: https://gallica.bnf.fr/ark:/12148/bpt6k1025111d/. Acesso em: 22 out. 2019. 
O estilo denominado montaria era tão comum na Inglaterra que passou a ser considerado um estilo nacional, apesar de variações dele já serem usadas no continente por mulheres desde o final do século XVII. Fortemente influenciado pela alfaiataria masculina, no fim do século XVIII, o traje ganhou grandes colarinhos e lapelas similares ao dos paletós masculinos. Igualmente inovadores eram os acessórios que o acompanhavam, incluindo coletes acinturados com pontas longas, tricórnios, luvas, chicotes, gravatas, botões e galardões em estilo militar (figura 8).

Esses maneirismos provocavam, obviamente, de maneira similar ao que ocorrera com Maria Antonieta quando era Delfina, incessantes críticas por parte dos comentadores e moralistas. Apesar das críticas, alguns consideravam esses trajes de montaria extremamente sedutores, exatamente por isso. Como o viajante St. John comentou:

\begin{abstract}
[...] não há nenhum outro traje europeu usado pelas mulheres da moda que exiba tão vantajosamente o formato de uma bela mulher. Os casacos abotoados abaixo dos seios permitem que adivinhemos seu formato redondo, os coletes apertados marcam as finas cinturas e as ajustadas botas de couro definem panturrilhas e coxas maravilhosas. Algumas usam até mesmo calças justas de lã e nenhuma saia ou anágua, o que nos permite vislumbrar o formato exato de toda a perna ${ }^{10}$. (ST. JOHN, 1804, p. 65)
\end{abstract}

A pitoresca e sedutora versão francesa dos trajes de montaria ingleses desenvolveu-se mais tarde do que sua versão original, e foi tão fortemente influenciada por ele que o nome em francês era redingote, uma adaptação do termo riding coat. Similar ao traje de montaria tradicional, o chamado redingote sob o Rei Sol, quando as cortesãs, sobretudo suas amantes, com frequência acompanhavam as caçadas reais. Mas foi somente no reinado de Luís XVI e Maria Antonieta que passaram a ser aceitos em espaços que não eram os de cavalgadas ou de caça, da mesma maneira como acontecia na Inglaterra havia décadas.

Inevitavelmente, algumas nuances dos costumes ingleses perdiam-se, tornando-se meras afetações. James Harris, primeiro Conde de Malmesbury, observou que as jovens francesas iam a jantares "em suas botas e esporas, porque acham aqui que essas são nossas Modas Inglesas, as quais graças a Deus ainda não são"11 (HARRIS, 1870, v. 1, p. 360). Em Paris, em 1785, quando foi a uma corrida de cavalos, Harris ficou chocado ao ver "mulheres da

\footnotetext{
${ }^{10}$ Tradução nossa para: "There is no other European attire worn by fashionable women which displays the shape of a fine woman in advantage. The overcoats, buttoned under the breasts, allow us to guess its round shape, tight vests mark the thin waists and the adjusted leather boots defined calves and thighs. Some even wear tight trousers and no skirt or petticoat, which allows us to glimpse the exact shape of the whole leg".

${ }^{11}$ Tradução nossa para: "in their bootsand spur, because they think here that is our English Fashion, which, thank God it is not yet".
} 
moda, usando botas e culotes de couro, mesmo que não cheguem nem perto de cavalos"12 (HARRIS, 1870, v. 1, p. 367). Igualmente inconformado, ele observou que os espectadores não apostavam nem se empolgavam, como os ingleses faziam, mas simplesmente assistiam passivamente, o que resultava em uma tarde bastante entediante. Maria Antonieta frequentava as corridas de cavalos e partidas de polo no Bois de Bologne, "trajada en amazone", uma mistura de traje esportivo e de espectador, absolutamente típico de seu zelo em seguir a tendência da anglomania.

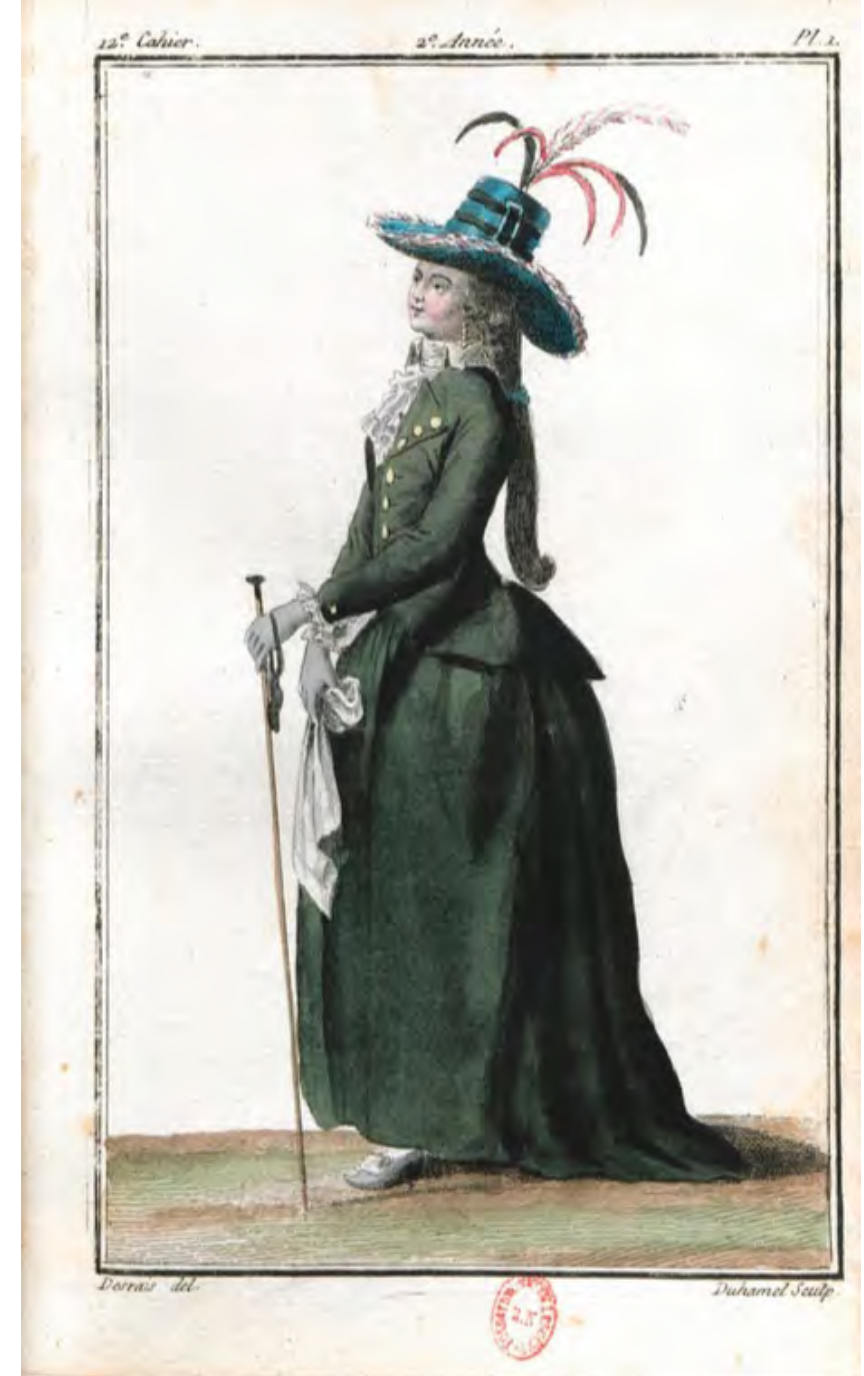

FONTE: Magasin des Modes Nouvelles Françaises et Angloises. $2^{\circ}$ Ano. $12^{\circ}$ caderno, 10 de março de 1787. Disponível em: https://gallica.bnf.fr/ark:/12148/bpt6k1025111d. Acesso em: 22 out. 2019.

\footnotetext{
${ }^{12}$ Tradução nossa para: "ladies of fashion, clad in boots and leather boots, even when they are not around horses".
} 
FIGURA 9 - DAME EN REDINGOTE DE SATIN LUMINEUX ET CORSET ROSE, AVEC CHAPEAU ENPLUMÉE... 1787. DUHAMEL (GRAVURA COLORIDA POR PRENSA, 34 X 26 CM)

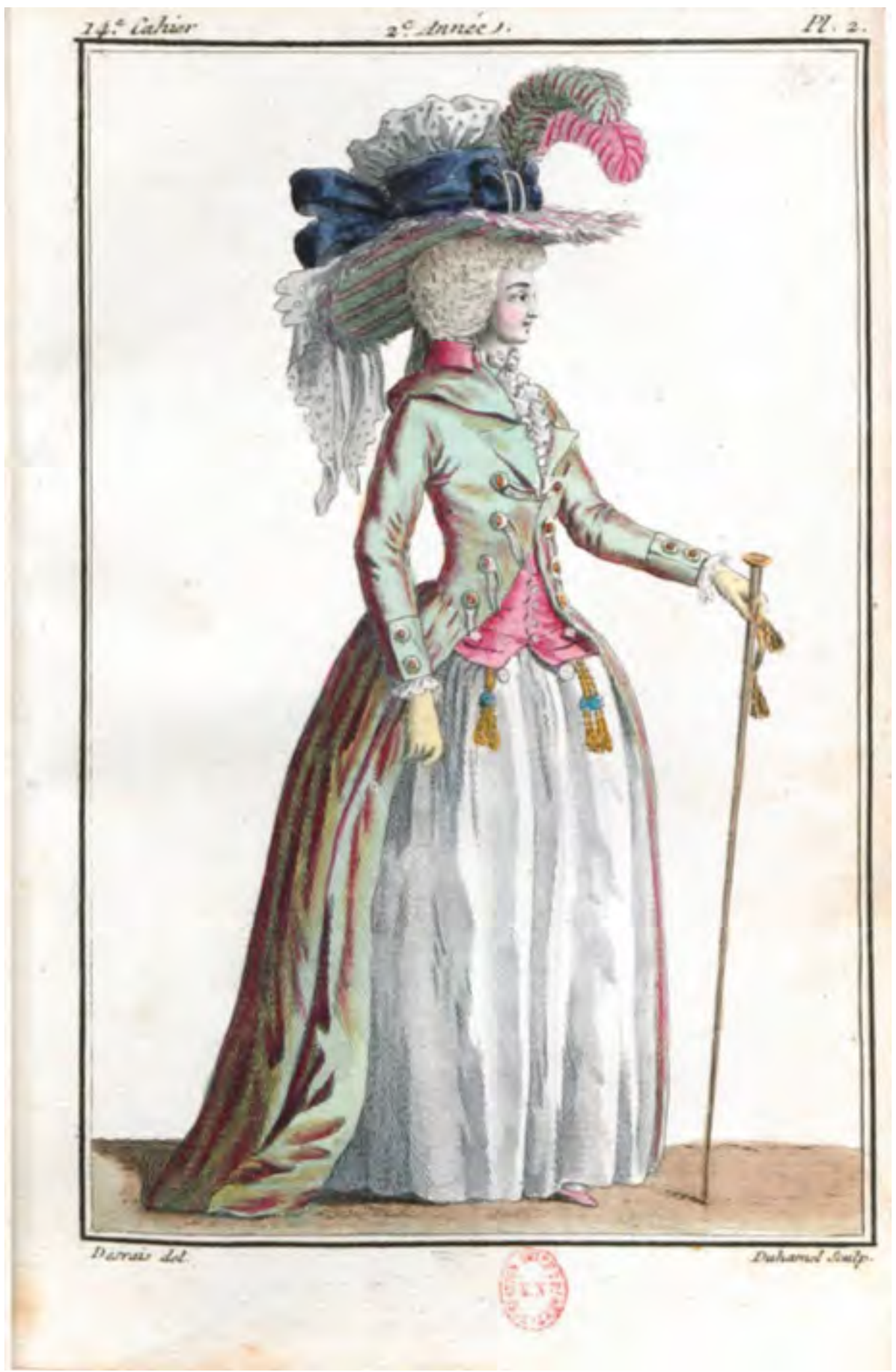

FONTE: Magasin des Modes Nouvelles Françaises et Angloises. $2^{\circ}$ Ano. $14^{\circ}$ caderno, 30 de março de 1787. Disponível em: https://gallica.bnf.fr/ark:/12148/bpt6k1025111d/. Acesso em: 22 out. 2019. 
Em 1771, apenas um ano antes de chegar a Versalhes, Maria Antonieta foi retratada em trajes de montaria pelo pintor austríaco Joseph Kreutzinger, como um presente a ser enviado para sua família em Viena. Então com 16 anos, ela usa um casaco ou sobretudo em estilo militar, feito de veludo vermelho com abotoaduras douradas, sobre um colete listrado com pontas triangulares pronunciadas; as luvas, o tricórnio e a vara que segura, aliados à postura relaxada, dão a impressão de que ela se prepara para montar (figura 10). A jovem Delfina acompanhava as cavalgadas do rei Luís XV, ainda que sua mãe, a imperatriz Maria Teresa, a criticasse por considerar essa atividade indecorosa e perigosa para uma mulher que desejava ter filhos. Apesar disso, Maria Teresa aprovou o quadro, pela semelhança com a filha e pela aparência de saúde que ele transmitia, e mandou pendurá-lo em seu gabinete privado. Quando usado em atividades privadas e em representações não oficiais, o traje de caça - ou de montaria - era bem aceito; porém, em público e em atividades formais, ele chocava pela afetação de uma ideia do que seria tipicamente inglês, mesmo que pouco tivesse a ver com o costume inglês.

Como seus predecessores, Luís XVI tinha paixão por cavalgadas, saindo à caça no parque de Versalhes quase que diariamente. Maria Antonieta também era uma habilidosa amazona, acompanhando frequentemente as caçadas do marido, usando o traje de montaria inglês e montando de pernas abertas como um homem desde que chegou à França, em 1770. Apesar disso, ela foi obrigada a abrir mão dessa prática por muitos anos ao ser criticada publicamente por não conseguir gerar um herdeiro. Os trajes femininos de montaria eram tão populares que, em 1772, o próprio Luís XV encomendou a Brun de Versoix, mestre da Académie Royale de Peinture et de Sculpture, uma pintura equestre para ser dada ao imperador José II da Áustria, irmão de Maria Antonieta. 0 quadro original atualmente encontra-se perdido, porém, em 1783, Maria Antonieta encomendou duas adaptações dele ao artista para decorar o Petit Trianon. De uma forma ousada, Brun de Versoix representou a rainha como uma intrépida amazona, usando calças justas e uma sobrecasaca no estilo frac anglaise, bastante masculina. A cena retratada não é, além disso, estática, conforme era a convenção de representação de figuras femininas: em primeiro plano, o cavalo da Delfina está com as patas dianteiras fora do chão, como se estivesse se preparando para um salto, e a pose de Maria Antonieta é desafiadora e vigorosa, segurando as rédeas e um chicote de forma impetuosa. Além disso, ela parece ser a personagem que lidera a fila de cavaleiros ao fundo. Em um deles pode-se, inclusive, ver-se claramente as calças compridas e culotes masculinos que usa, além de uma sela bastante específica - a dos guardas húngaros da Corte de Viena (figura 11). 


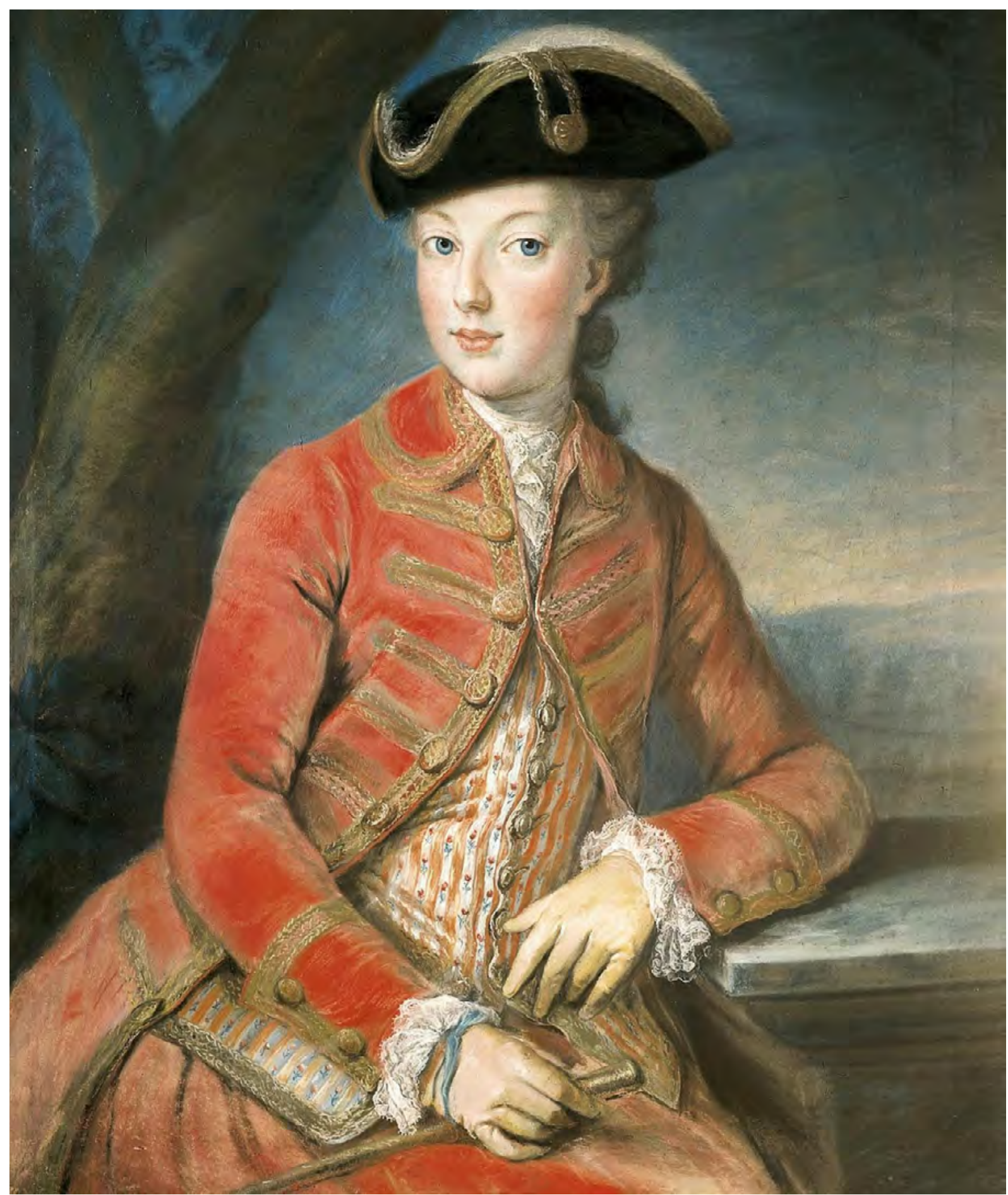

FONTE: Palácio de Schönbrunn, Viena.

Disponível em: https://www.habsburger.net/en/node/2776. Acesso em: 22 out. 2019. 
FIGURA 11 - COPIE DE MARIE ANTOINETTE, REINE DE FRANCE A CHEVAL. 1783. LOUIS AUGUST BRUN, DIT. BRUN DE VERSOIX (ÓLEO SOBRE TELA, 59 X 64 CM)

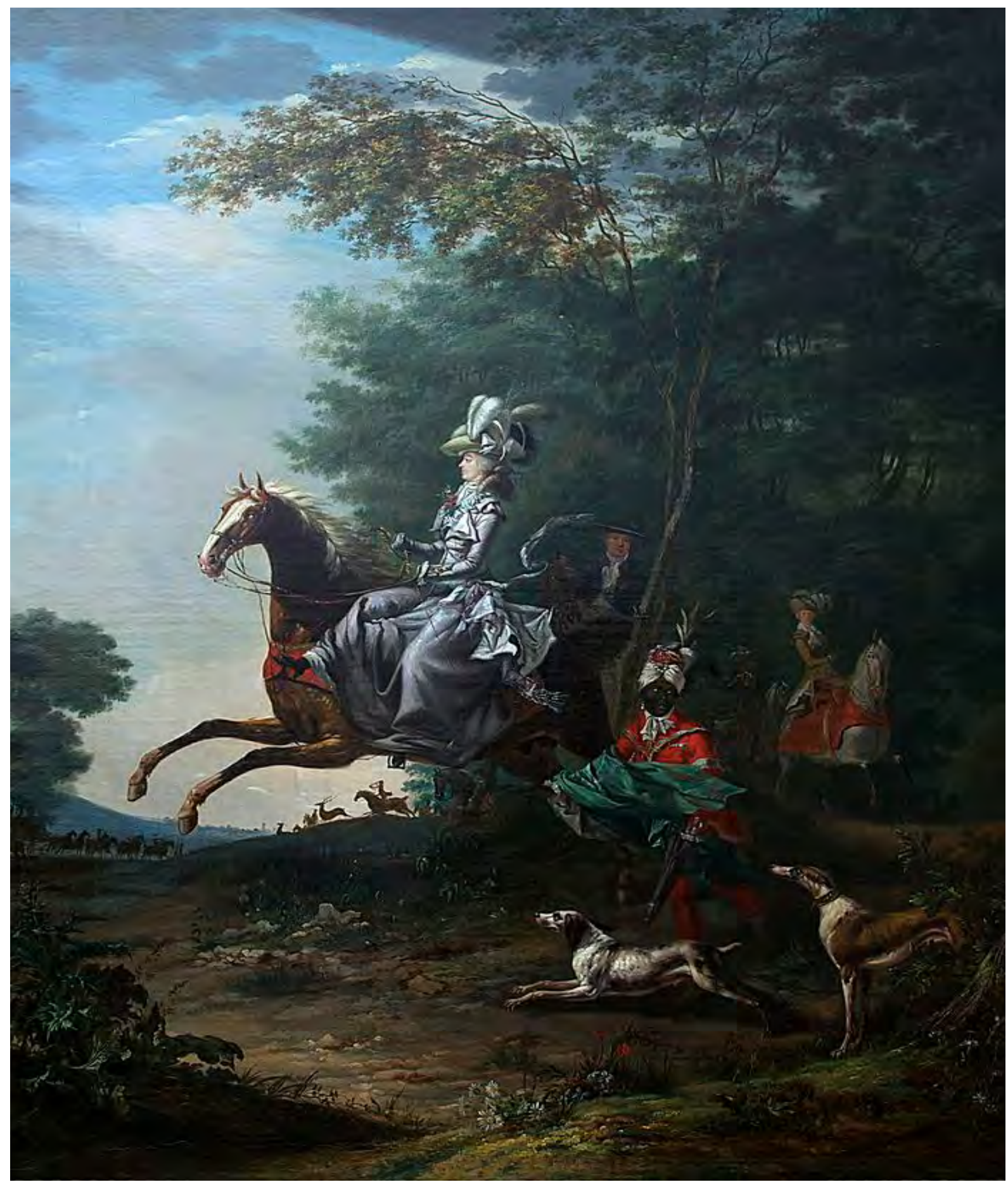

FONTE: Palácio de Versalhes e do Trianon, Versalhes. Disponível em : http://collections.chateauversailles. fr/\#9544162e-59e5-4b7a-ab58-8ef951727594. Acesso em: 22 out. 2019. 


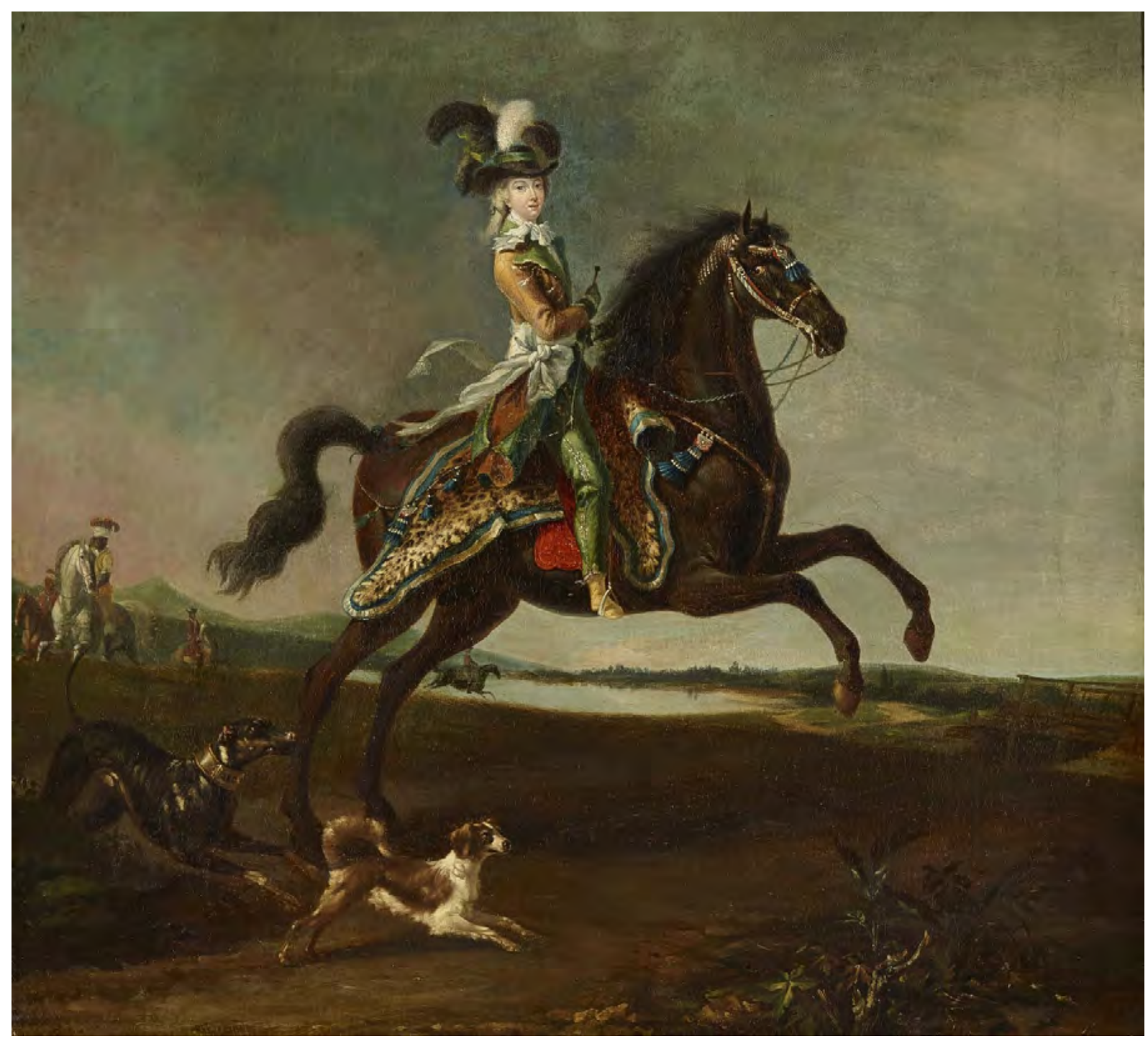

FONTE: Palácio de Versalhes e do Trianon, Versalhes. Disponível em: http://collections.chateauversailles. fr/\#41dc096c-de85-4e9d-ab62-f5322ce0ca57. Acesso em: 22 out. 2019.

A primeira cópia é evidentemente mais formal e menos polêmica por retratá-la usando um amplo traje de montaria acinzentado com uma camisa de gola rendada e uma pequena gravata; um chapéu de feltro com plumas altas completa o visual claramente inspirado na anglomania. Ao contrário da cópia em que ela usa calças, esse retrato foi exibido na Grand Gallerie de Versalhes, em 1784, sendo considerado, portanto, um quadro oficial. Esse fato nos leva a concluir que, dado o momento de entusiasmo com as modas inglesas, o quadro foi recebido como um posicionamento de Maria Antonieta, por meio de uma representação oficial sua, favorável à crescente anglomania (figura 11). 
Maria Antonieta abraçou com entusiasmo, após dar à luz ao Delfim Luís José em 1781, os hábitos ingleses. Passou a usar o traje de montaria e o redingote no Petit Trianon e o exibia pelos jardins de Versalhes. Ela também começou a usar tecidos importados da Inglaterra ou tecidos franceses em cores mais sóbrias que eram consideradas à l'anglaise, patrocinando, inclusive, tecelões para que criassem tecidos em tons únicos para ela, como o couleur de noisette (cor de nozes) ou o aux puces (um marrom acinzentado mais ou menos do tom das pulgas). Também começou a ser notado que ela passou a usar pouco rouge e quase nenhum ceruse e deixou de empoar os cabelos e repuxá-los para cima, como na época do pouf, adotando um penteado mais simples e baixo. Todas essas coisas indicam sua busca por um estilo mais natural e privado, uma vez que coincide com seus, cada vez mais frequentes, retiros no Petit Trianon. 0 fato de que a França se encontrava em uma verdadeira guerra comercial com a Inglaterra não impedia que a rainha estimulasse a anglomania. As críticas que passou a receber na década de 1780 dizem muito sobre isto:

\begin{abstract}
[...] retirada em sua Pequena Viena, a rainha usa roupas inglesas, chapéus ingleses e corresponde-se com damas inglesas. Comerciantes de seda, cetim e brocado, até então muito bem recebidos por Nossa Majestade, são proibidos de entrar em seu palacete, mas assistem enraivecidos rolos e rolos de panos rústicos, lisos e sem graça nenhuma, todos importados da Inglaterra, passarem por suas por$\operatorname{tas}^{13}$. (MERCIER, 1800, v. 2, p. 344)
\end{abstract}

A repentina predileção de Maria Antonieta pelo embaixador inglês, Duque de Dorset, por Georgiana de Devonshire e outros frequentes viajantes ingleses - para não mencionarmos as gazes, lãs, luvas e botas, além, é claro, dos vestidos à l'anglaise - despertaram ciúmes amargos entre os aristocratas mais velhos e conservadores, assim como sua predileção por coisas austríacas havia provocado quando era ainda Delfina. Como Lady Craven notou, quando esteve em Versalhes, em 1783: “[...] a Rainha - eles insistem nos corredores cheios de mexericos da Corte - não ama a França e qualquer coisa que seja identificada como francesa, enquanto, por estrangeiros e coisas estrangeiras, ela demonstra uma forte parcialidade" $^{14}$ (CRAVEN citada por LOUGH, 1987, p. 416).

\footnotetext{
${ }^{13}$ Tradução nossa para: "[...] withdrawn in her Petite Vienna, the queen wears English clothes, English hats and corresponds with English ladies. Traders of silk, satin and brocade, until then very well received by Our Majesty, are forbidden to enter her palace, but watch racy rolls and rolls of rustic, plain and unpleasant cloths, all imported from England, pass through its doors".

${ }^{14}$ Tradução nossa para: "The Queen, they insist, at the Court's halls full of gossips, does not love the French and anything that is identified as French, while for foreigners and all the things foreigners she betrays a strong partiality".
} 


\section{Os riscos e significados revolucionários da anglomania}

Luís XVI não compartilhava o entusiasmo dos parisienses e de sua esposa pelas coisas inglesas, que eram, apesar de tudo, fabricações dos inimigos políticos e rivais econômicos tradicionais da França. 0 rei envolveu-se em uma cruzada pessoal contra o penteado cadogan (também chamado catogan ou catacoua), um estilo de penteado masculino bastante associado à anglomania. Batizado em homenagem ao Conde de Cadogan, segundo em comando da armada dirigida pelo Duque de Marlborough que havia derrotado a França na Guerra de Independência Americana, o penteado consistia em dobrar a franja sobre si mesma, prendendo-a com um ou dois grampos, formando uma fofa onda de cabelos, como um topete, na frente da cabeça. A parte traseira era simplesmente escovada e amarrada em um rabo de cavalo com um laço. Era um estilo simples, rápido e de baixa manutenção, apropriado para um militar - ou para uma mulher ativa. Por volta de 1783, o cadogan havia rompido as barreiras de gênero. A Baronesa d'Oberkirch credita à Duquesa de Bourbon, nora de Luís XVI e Maria Antonieta, o estilo até então reservado aos homens, relembrando que "nada era mais bonito ou galante quando usado com cadenettes [cachos laterais], pequenos chapéus e plumas ${ }^{15 "}$ (FREUDSTEIN, 1869, v. 2, p. 95). 0 cadogan podia até ser visto na cabeça de alguns monarcas europeus, como na de Frederico II da Suécia e na de Catarina, a Grande. Em 1783, uma crônica das Memóires sécrets ${ }^{16}$ relatou:

\footnotetext{
O rei, após voltar de uma caçada, teve seu cabelo penteado em um chignon [coque] à maneira feminina, e foi em seguida até os apartamentos da rainha. Isso fez Sua Majestade rir ardentemente e ela perguntou a ele o que aquela mascarada significava. Havia a temporada de carnaval retornado? Você acha isso feio? - o nobre esposo perguntou a ela. - É uma moda que quero iniciar! Nunca comecei nenhuma.
}

\footnotetext{
${ }^{15}$ Tradução nossa para: "Rien n’était plus beau ou galant quand il était porté avec des cadenettes, des petits chapeaux et plumes".

${ }^{16}$ As Mémoires sécrets são um conjunto de crônicas anônimas sobre eventos que ocorreram entre 1762 e 1788. Dena Goodman (1996) acredita que elas começaram como uma espécie de folhetim manuscrito que circulava em Paris e que passou a ser publicado pela primeira vez em Londres como um conjunto de vários volumes encadernados, a partir de 1783. Assim, embora cada crônica tenha datas exatas, elas não foram publicadas até muito depois dos eventos que descrevem. Elas, porém, apresentam uma abundância de detalhes sobre a vida literária e as maledicências que circulavam em Paris nas vésperas da Revolução. De acordo com Goodman: "Advåinda do centro dos mais brilhantes debates do quarto final do século, seja no que fosse relativo à batalha contra os jesuítas ou a oposição do Parlamento de Paris às políticas do Rei, ou assuntos bem conhecidos e mexericos, tais como o Caso do Colar de Diamantes, o surgimento de novas estéticas como o drama burguês, a Ópera Gluckista, as obras de Shakespeare, esse conjunto de escritos nos transmite um relato interessante, quase do dia-a-dia parisiense, de uma maneira às vezes envolvida e às vezes distanciada, indignada ou sarcástica, de movimentos efêmeros ou profundos da opinião pública, enquanto ainda se constituíam" (G0ODMAN, Dena. The Republic of Letters: a cultural history of the French Enlightenment. Ithaca e Londres: Cornell University Press, 1996, p. 144).
} 


\begin{abstract}
- Ah, Sire! Cuidado com essa, é horrível - Sua Majestade retrucou. -Contudo, madame - continuou o Monarca - os homens realmente devem ter uma maneira de arrumar seus cabelos que os distinga das do seu sexo; você já nos tirou as plumas, o chapéu e as tranças. Agora só esse cadogan restou e penso que ele é muito feio nas mulheres... A rainha entendeu o que ele estava querendo dizer, e não tendo nenhum desejo além de agradar o rei, deu ordens para que as mulheres desfizessem seus cadogans de uma vez por todas e readotassem os coques e poufs. Parece que essa moda, adotada com paixão em Paris pelas petites-maîtresses, e que é realmente muito ridícula, irá morrer devido à piada do rei ${ }^{17}$. (MÉMOIRES SECRETS, crônica 30 de agosto de 1784)
\end{abstract}

A campanha de Luís XVI contra a crescente anglomania não se resumiu, porém, a tiradas inteligentes sobre as modas femininas. Alarmado pela crescente popularidade de algodões e lãs advindas da Inglaterra, a partir de 1783, o Conselho Real lançou uma série de decretos proibindo ou taxando a venda de tecidos e outros bens têxteis importados na França. Em setembro de 1785, Thomas Jefferson, então embaixador americano em Versalhes, observou ironicamente: "A Rainha está determinada, graças à ação direta do marido, a voltar a usar somente gazes e sedas francesas daqui para frente. Quantos teares ingleses serão postos abaixo por isso?"18 (JEFFERSON, 1785, carta 8, 2 de abril).

0 Tratado de Éden, assinado no fim de 1786, buscou por fim à crescente guerra comercial entre as duas nações, mas, na prática, acabou por facilitar as importações de certos bens da Inglaterra para a França. 0 tratado inundou o mercado francês de ferro inglês (acier), que rapidamente substituiu metais preciosos e pedras em espadas, floretes, fivelas, botões, correntes e joias (sobretudo as femininas). Os bens têxteis representavam o ponto principal de discórdia nas negociações. Além de certos tipos de gaze de seda, linho e lã, a França dependia da produção inglesa de musselinas e tecidos de algodão, que eram importados da Índia (colônia inglesa) pela Companhia das Índias Orientais. Os franceses finalmente foram obrigados a aceitar que esses itens não fossem mais sobretaxados por um motivo:

\footnotetext{
${ }^{17}$ Tradução nossa para: "Après son retour de chasse, le roi se fait coiffer ses cheveux en chignon à la manière féminine, puis se rend chez la reine. Cela a fait rire sincèrement Sa Majesté et elle lui a demandé ce que signifiait cette mascarade. La saison du carnaval est-elle revenue? Pensez-vous que c'est moche? le noble mari lui a demandé. - C'est une mode que je veux commencer! Je n'en ai jamais eu. - Ah, Sire! Faites attention à cela, c’est horrible, a répondu Sa Majesté. - Mais, madame, continua le monarque, - les hommes doivent avoir un moyen de disposer leurs cheveux qui les distinguent de leur sexe; Vous avez déjà enlevé les plumes, le chapeau et les tresses. Maintenant, ce cadogan est laissé seul, et je le trouve très laid chez les femmes... La reine comprit ce qu'il voulait dire, et n'ayant aucun désir mais de plaire au roi, il donna ordre aux femmes de déballer leurs cadogans une fois pour toutes et de se réajuster cokes et poufs. Il semble que cette mode, adoptée avec passion à Paris par les petites maîtresses, et qui est vraiment très ridicule, mourra à cause de la blague du roi".

${ }^{18}$ Tradução nossa para: "The Queen is determined, thanks to the direct action of her husband, to return to using only French gauzes and silks from now on. How many English looms will be put down for this?".
} 
não havia outra maneira de impedir que fossem contrabandeados para dentro do país. Ainda assim, Luís XVI impôs altas taxas alfandegárias, esperando, dessa maneira, desencorajar a venda desses tecidos. Ao mesmo tempo, concedeu diversas benesses comerciais para a produção de sedas, cetins, veludos e brocados franceses. Essas medidas, porém, não alcançaram sucesso. Em setembro de 1787, as Mémoires sécrets reclamaram: “Queremos apenas draps [tecidos de algodão grosso e resistente] ingleses que, frequentemente, são mais bem feitos e mais baratos que os nossos, o que faz com que esses tratados comerciais ainda sejam mais desvantajosos". De fato, os trajes ingleses alcançaram o pico de popularidade sob o Tratado de Éden.

As medidas adotadas por Luís XVI fracassaram perante a crescente anglomania. Nem a participação efetiva de Maria Antonieta na empreitada conseguiu diminuir a influência que os trajes ingleses tinham sob as petites-maîtresses e os petits-maîtres de Paris. Madame Campan relembra que

[...] após conversas particulares com o marido, ela parece, finalmente, ter entendido os perigos das modas inglesas, não apenas para sua imagem como para a glória de nossa Nação. Seu augusto marido explicou a ela os problemas de toda ordem que esse frisson estava causando. A partir daí a Rainha decidiu abdicar de seus trajes e tecidos ingleses e voltou-se, novamente, para as marchandes de Paris, voltando a receber Madame Bertin no Trianon. As sedas, cetins, veludos, fitas e laços franceses voltaram a adorná-la e ela com frequência usa um novo e fresco estilo quando vai a Paris, ainda que seja recebida, para sua surpresa e exasperação, com olhares maldosos e algumas risadas por parte das jovens da moda do Palais Royal ${ }^{19}$. (CAMPAN, 1852, p. 265)

Pela primeira e única vez, Maria Antonieta falhava em ditar e dar o exemplo em matéria de roupas e adornos, fracassando em ditar o que deveria ser copiado e adaptado pelas petites-maîtresses. A Baronesa d'Oberkirch rememorou:

Fomos a Paris assistir a Ópera, e a Rainha usava uma das chemises criadas especialmente para ela por Madame Bertin em um bela gaze de seda azul clara com fitas e detalhes em rosa pálido, além de um belo manto com capuz feito de veludo azul celeste da monarquia, com uma barra branca claríssima. Apesar disso, ela foi recebida com a maior frieza na Ópera e até mesmo percebemos alguns olhares de

\footnotetext{
${ }^{19}$ Tradução nossa para: "[...] after private conversations with her husband, she seems at last to have understood the dangers of this English fashions, not only for her image but for the glory of our Nation. Her august husband explained to her the problems of all order that this frisson was causing. Further on, the Queen decided to abdicate her English costumes and clothing, and turned again to the Parisian marchandes, again meeting with Madame Bertin at the Trianon. French silks, satins, velvets, ribbons, and bows adorned her again, and she often uses a new, fresh style when she goes to Paris, even though she is received, to her surprise and exasperation, with evil eyes and a few laughter, from the young fashionable ladies of the Palais Royal".
} 
soslaio e julgamento para ela e nosso grupo, todo vestido em estilos semelhantes ao dela. Pela primeira vez, ela não era a mulher mais à la mode do recinto, o que perceptivelmente a incomodou ${ }^{20}$. (FREUDSTEIN, 1869, v.1, p. 154)

0 fracasso do casal real em conter o gosto por tudo que viesse da Inglaterra pode ser explicado pelo fato de a moda ser fortemente influenciada por tendências concomitantes no campo da política. Voltaire e Rousseau haviam visitado a Inglaterra em 1726 e 1735, respectivamente, retornando à França entusiasmados com a monarquia parlamentar e constitucional, considerada bastante democrática e avançada. Rousseau chegou até mesmo a comparar as conveniências dos trajes ingleses com as liberdades concedidas pela adoção de um parlamento e de uma Carta Constitucional. Era impossível apreciar e vestir as modas advindas da Inglaterra sem apreciar o subtexto político que elas continham. Nesse sentido, em meados da década de 1780, a modas à l'anglaise passaram a estar, inexoravelmente, entrelaçadas às ideias radicais que rapidamente explodiriam na Revolução. 0 Conde de Ségur, assim como outros nobres mais conservadores, via na anglomania um augúrio sinistro - e que parece ter passado despercebido até que fosse tarde demais para a monarquia absolutista francesa:

Sempre fiquei muito surpreso que o nosso governo e os nossos estadistas, ao invéz de criticar a sede por modas inglesas, que repentinamente espalharam-se pela França, por serem frívolas tolas e pouco francesas, não percebendo nelas o desejo de outro tipo de imitação, e os germes de uma potente revolução nas mentes: eles não estavam nem um pouco cientes que ao destruírem os caminhos retos de nossos parques, os quadrados simétricos de nossa topiaria e as vizinhanças uniformes, para transformar tudo em tortos e irregulares jardins ingleses, estávamos declarando nosso desejo de parecermos com essa nação em outros pontos de natureza e razão.

Nossos líderes não viram que o frac, os coletes e os culotes que substituíram os amplos e imponentes trajes da antiga corte encobriam uma preferência geral por igualdade, e que, ainda não podendo brilhar em assembleias públicas como os lords e deputados ingleses, gostaríamos finalmente de nos distinguirmos por nós mesmos, como eles, pela magnificência de nossos cargos públicos, pelo esplendor de nossas falas e pela rapidez de nossos garanhões, e não mais pela tradição

\footnotetext{
${ }^{20}$ Tradução nossa para: “Nous sommes allés à Paris pour regarder l'Opéra. La reine portait l'une des chemises créées spécialement pour elle par Mme Bertin dans une belle gaze de soie bleu pâle avec des rubans et détails en rose pâle, ainsi qu'un beau manteau à capuchon en velours bleu ciel monarchie, avec une barre blanche claire. Malgré cela, elle a été reçue avec la plus grande froideur à l'Opéra et a même remarqué quelques regards de côté et de jugement sur elle et notre groupe, tous vêtus de styles similaires au sien. Pour la première fois, elle n'était pas la femme plus à la mode de la pièce, ce qui la dérangeait".
} 
de nossa posição de nascimento. Entretanto, nada poderia ter sido mais fácil de adivinhar, e era suficiente conversar com aqueles indivíduos da moda, que apinhavam toda Paris, e que foram os primeiros a nos trazer essas malditas modas, a fim de entender que eles não pretendiam limitar suas visões a tais imitações superficiais $^{21}$. (SÉGUR, 1825. p. 344)

\section{Considerações finais}

Para a Baronesa d'Oberkirch, a onda de anglomania significou não apenas uma mudança dos desejos políticos, mas uma sumária rejeição dos valores da aristocracia e da monarquia absolutista francesa:

Queremos ser ingleses a qualquer custo, e essa pretensão apaga nosso caráter nacional. Procuramos esquecer nosso passado para encontrarmos um novo futuro. Procuramos apagar nossas modas, nossos costumes, para nos tornarmos como os vizinhos que odiamos ${ }^{22}$. (FREUDSTEIN, 1869, v. 2, p. 246)

Nas vésperas da Marcha sobre Versalhes, em outubro de 1789, o embaixador americano - nenhum estranho a violento reveses políticos - relatou que "tudo é à l'anglaise aqui agora, sobretudo em Paris, e o desejo de imitar os ingleses prevalece tanto no corte de um casaco como no desejo de uma Constituição"23 (MORRIS, 1888, vol. 1, p. 31).

As liberdades anteriormente profetizadas por Voltaire e Rousseau finalmente pareciam estar ao alcance; por toda a França, cidadãos das mais diversas classes sociais adotavam as ideias burguesas advindas da Inglaterra, de monarquia parlamentar e constitucional,

\footnotetext{
${ }^{21}$ Tradução nossa para: "I have always been very surprised that our government and our statesmen, rather than criticizing our thirst for English fashions, which suddenly spread through France as frivolous, foolish and little French like, not realizing in them the desire for another kind of imitation, and the germs of a potent revolution in minds: they were not at all aware that by destroying the straight paths of our parks, the symmetrical squares of our topiary and the uniform neighborhoods, to turn everything into crooked and irregular English gardens, we were declaring our desire to resemble this nation in other points of nature and reason. Our leaders did not see that the frac, jackets, and coats that replaced the large, imposing costumes of the old court, overshadowed a general preference for equality, and which, while not being able to shine in public assemblies like the English lords and deputies, we want to distinguish ourselves, like them, by the magnificence of our public offices, by the splendor of our speeches and by the rapidity of our stallions, and no longer by the tradition of our position of birth. However, nothing could have been easier to guess, and it was enough to talk to those fashionable people who crowded all over Paris, and who were the first to bring us these darned fashions, in order to understand that they did not intend to limit their visions to such surface imitations".

22 Tradução nossa para: "Nous voulons être anglais à tout prix, et cette prétention efface notre caractère national. Nous essayons d'oublier notre passé afin de trouver un nouvel avenir. Cherchons à effacer nos modes, nos coutumes, à devenir comme les voisins que nous déteston".

${ }^{23}$ Tradução nossa para: "Everything is à l'anglaise here now, especially in Paris, and the desire to imitate the English prevails both in the cut of a coat and in the desire for a constitution".
} 
tão rapidamente como as petites-maîtresses adotavam os trajes ingleses, com consequências que iam desde o desejo por reformas até sonhos de Revolução. Inicialmente, as petites-maîtresses e os petits-maîtres eram apenas um título, um adjetivo dado e usado por aqueles indivíduos, não importando a classe social, que proclamavam seu ardor às novas e sempre cambiantes tendências de indumentária. Combinados com a anglomania, porém, esses indivíduos passaram a disseminar e a divulgar mais do que apenas a superficialidade da moda e dos estilos a serem copiados. Embreados nos trajes de inspiração inglesa estavam o desejo por mudança e o questionamento da sacralidade atemporal da monarquia absolutista Bourbon, com seu rígido sistema de distinção, exibição e privilégios da minoria aristocrática.

\section{Referências}

CHRISMAN-CAMPBELL, Kimberly. Fashion victims: dress at the court of Louis XVI and Marie-Antoinette. Londres: Yale University Press, 2015.

DELPIERRE, Madeline. Dress in France in the Eighteenth-century. New Haven e Londres: Yale University Press, 1997.

FOREMAN, Amanda. Georgiana, Duquesa de Devonshire. São Paulo: Objetiva, 2012.

GHERING VAN IERLANT, Marie J. Anglo-French fashion, 1786. Revista Costume, Londres, v. 17, março de 1983.

GOODMAN, Dena (Org.). Marie-Antoinette: writing on the body of a queen. Nova York: Reutledge, 2003.

LE FAYE, Deirdre. Jane Austen's “outlandish cousin”: the life and letters of Eliza de Feuillide. Londres: British Library, 2002.

LIMA, Laura Ferrazza de. Quando a arte encontra a moda: a obra de Antoine Watteau na França do século XVIII. Porto Alegre: Editora Zouk, 2018.

LOUGH. John. France on the eve of Revolution: british travellers' observations (1763-1788). Londres: Croom Helm, 1987, p. 416.

NOLAN, Brian. Ladies of the Grand Tour. Londres: HarperCollins, 2001.

RIBEIRO, Aileen. Dress in eighteenth-century Europe (1715-1789). Londres: Yale University Press, 2001. 
ROCHE, Daniel. A cultura das aparências: uma história da indumentária (séculos XVIIXVIII). São Paulo: Editora SENAC, 2007.

WEBER, Caroline. Rainha da moda: como Maria Antonieta se vestiu para a Revolução. Rio de Janeiro: Jorge Zahar Ed., 2008.

\section{Memórias e anedotários}

Anon. Mémoires secrets pour servir à l'histoire de la République des Lettres en France depuis 1762 jusqu'à nos jours. N/d. Disponível em: https://gallica.bnf.fr/ark:/12148/ bpt6k6329707. Acesso em: nov. 2019.

CAMPAN, Henriette. Memoirs of the court of Marie-Antoinette, queen of France. 1852. Disponível em: https://archive.org/details/memoirsofcourto1v2camp. Acesso em: nov. 2019.

CARACCIOLI, Louis-Antoine de. Voyage de la raison en Europe. Disponível em: http:// gallica.bnf.fr/ark:/12148/bpt6k97790341. Acesso em: nov. 2019.

FREUDSTEIN, Henriette Louise de Waldner. Mémoires de la Baronne d'Oberkirch. 1869. Disponível em: https://gallica.bnf.fr/ark:/12148/bpt6k2048423. Acesso em: nov. 2019.

FORDYCE, James. Sermon to young women (1766). Londres: Forgotten Books, 2018.

HARRIS, James. A series of letters of the first earl of Malmesbury, his family and friends from 1745 to 1820. Londres: Richard Bentley, 1870.

JEFFERSON, Thomas. The papers of Thomas Jefferson. Disponível em: https:// jeffersonpapers.princeton.edu/volumes. Acesso em: nov. 2019.

MERCIER, Louis-Sébastien. The new picture of Paris. Londres: H. D. Symonds, 1800.

MERCIER, Louis-Sébastien. Tableau de Paris. Disponível em: http://gallica.bnf.fr/ ark:/12148/bpt6k65711801. Acesso em: nov. 2019.

SÉGUR, Louis Philippe. Memoirs or recollections of Count Ségur. 1825. Disponível em: https://archive.org/details/memoirsrecollect00sg/page/n3. Acesso em: nov. 2019.

ST. JOHN, James. Letters from France to a gentleman in the south of Ireland, written in 1787. 1803. Disponível em: https://books.google.com.br/books?id=_Z9CAAAAYAAJ\&. Acesso em: nov. 2019.

WALPOLE, Horace. The letters of Horace Walpole. Editado por P. Toynbee. Oxford: Oxford University Press, 1915. 